\title{
Synthesis, X-ray crystal structure and antimycobacterial activity of enantiomerically pure 1-ethyl-2,3-dicyano-5-(het)aryl-6-hetaryl-1,6- dihydropyrazines
}

\author{
Egor V. Verbitskiy, ${ }^{\text {a,b }}$ Maria S. Toporova, ${ }^{\text {a }}$ Mikhail I. Kodess, ${ }^{\text {a }}$ Marina A. Ezhikova, \\ Maksim L. Isenov, ${ }^{\text {a }}$ Marina G. Pervova, ${ }^{a}$ Marionella A. Kravchenko, ${ }^{c}$ Igor D. Medvinskiy, \\ Sergey N. Skornyakov, ${ }^{c}$ Gennady L. Rusinov, ${ }^{\text {a,b }}$ and Valery N. Charushin ${ }^{a, b}$ \\ ${ }^{a}$ I. Postovsky Institute of Organic Synthesis, Ural Branch of the Russian Academy of Sciences, \\ S. Kovalevskoy Str., 22, Ekaterinburg, 620990, Russia \\ ${ }^{b}$ Ural Federal University, Mira St. 19, Ekaterinburg, 620002, Russia \\ ${ }^{c}$ Ural Research Institute for Phthisiopulmonology, 22 Parts'ezda, 50, Ekaterinburg, 620039, \\ Russia \\ E-mail: Verbitsky@ios.uran.ru
}

\section{Dedicated to Professor Oleg N. Chupakhin on the occasion of his 80th anniversary}

DOI: $\underline{\text { http://dx.doi.org/10.3998/ark.5550190.p008.690 }}$

\begin{abstract}
The Petasis reaction of 6-alkoxy adducts of 1-alkyl-2,3-dicyano-5-arylpyrazinium salts with aromatic boronic acids, such as 2-thienylboronic, 2-furanylboronic and 3-thienylboronic acids, or their benzo analogs in dichloromethane proceeds smoothly at room temperature with the formation of the corresponding 5-aryl-6-hetaryl substituted 1,6-dihydropyrazine derivatives. All dihydropyrazines were separated as pure enantiomers by chiral HPLC, and their absolute configurations for each pair of enantiomers have been determined by X-ray analysis. Individual enantiomers were screened in vitro for their antimycobacterial activities against Mycobacterium tuberculosis $\mathrm{H}_{37} \mathrm{Rv}$, avium, terrae and extensively drug-resistant and multi-drug-resistant strains isolated from tuberculosis patients in Ural region (Russia). It has been shown that several compounds exhibit a good level of antituberculosis activity compared to the reference drugs.
\end{abstract}

Keywords: Pyrazines, Petasis reaction, antituberculosis activity, extensively drug-resistant and multi-drug-resistant tuberculosis

\section{Introduction}

Tuberculosis is an illness that results from infection with Mycobacterium tuberculosis (MTB). Tuberculosis is responsible for millions of human deaths annually, claiming more lives than any 
other single infectious agent. ${ }^{1-3}$ Almost one-third to one-half of the world's population is infected with M. tuberculosis and approximately $10 \%$ of infected individuals will experience active disease at some time in their life. ${ }^{4}$ Currently, treatment for active Tuberculosis includes at least 6 months of therapy with the first line drugs, such as isoniazid, rifampicin, pyrazinamide and ethambutol. ${ }^{5-7}$ Failure of patients to complete a full treatment protocol and the outbreak of acquired immune deficiency syndrome (AIDS) has resulted in the emergence of multi-drug resistance (MDR). Recent estimates show that $10 \%$ of all new tuberculosis infections are resistant to at least one antituberculosis drug. Subsequently, the World Health Organization (WHO) has declared tuberculosis as global public health emergency. ${ }^{8}$ For multi-drug resistance (MDR) and extensively drug resistance (XDR) combinations of the first line drugs and the second line drugs, such as aminoglycosides, fluoroquinolones, thioamides, cycloserine and $p$ amino salicylic acid are used. ${ }^{9}$ Since the discovery of rifampicin in 1960, there is no more drugs developed to treat tuberculosis. The third line drugs include rifabutin, clarithromicin, linezolid, thiacetone, arginine and vitamin $\mathrm{D}$, which are still being developed, have less or unproven efficacy and are very expensive. ${ }^{10}$ MTB have the cell with a high lipid content, thus resulting in a high degree of lipophilicity and resistance to alcohol, acids, alkali and some disinfectants. ${ }^{11}$

It is worth noting that practically all drugs used to treat tuberculosis are capable of causing toxic side effects. ${ }^{11}$ Therefore, it is obvious that new original drugs that are more active and effective than the existing ones are supposed to be discovered. In addition, pyrazinecarbonitrile analogs (pyrazinecarboxamide and pyrazine-2-carboxylic acid derivatives) are important and famous as the first-line antituberculosis drugs. ${ }^{11}$

It is known that the addition reaction of 1,4-diazines and their benzo derivatives is of great importance for the synthesis of biologically active compounds, including alkaloids. ${ }^{12-17}$ In order to cause these transformations azaaromatic compounds are usually activated by quaternization to obtain $N$-alkyl-1,4-diazinium salts. ${ }^{17,18}$ Indeed, it has recently been shown that 1-alkyl-1,4diazinium cations are prone to add carbo- and heteroatomic nucleophiles to give mono- and diadducts, or to be transformed into condensed tetrahydropyrazines through the tandem addition reactions with bifunctional nucleophiles. ${ }^{17-26}$ On the other hand, the Petasis reaction is one of the multicomponent condensation reactions, which provides a convenient method for the preparation of $\alpha$-amino acids by reacting an amine $\mathbf{1}$ with a carbonyl compound $\mathbf{2}$ and a boronic acid $\mathbf{3}^{27-34}$ The reaction proceeds via the formation of aminal intermediate 4 (Scheme 1).

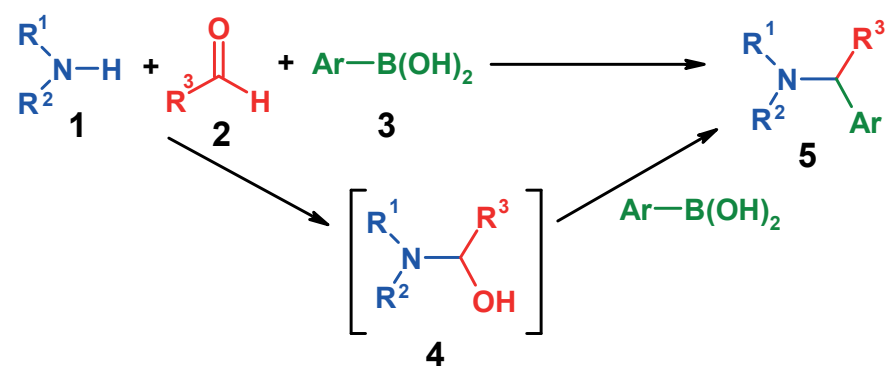

Scheme 1. The Petasis reaction with aryl boronic acid. 
The reaction has also been applied to the synthesis of heterocyclic systems ${ }^{35-40}$ and solid phase synthesis of peptides. ${ }^{41-43}$ The reaction is a very efficient with alkenyl and electron-rich aromatic boronic acids. In addition to primary amines, the secondary amines, sterically hindered primary amines, and tertiary aromatic amines can also participate in these transformations. A mild, practical, and novel method for the $\mathrm{C}-\mathrm{C}$ bond formation in the series of pyrazine (quinoxaline) derivatives by using the Petasis reaction has been developed through intermediacy of 6-alkoxy-1-ethyl-1,6-dihydropyrazines. All obtained dihydropyrazines were screened in vitro for their antimycobacterial activities against Mycobacterium tuberculosis $\mathrm{H}_{37} \mathrm{Rv}$, avium, terrae and extensively drug-resistant and multi-drug-resistant strains isolated from tuberculosis patients in Ural region (Russia). It has been found that some of these compounds exhibit a high tuberculostatic activity comparable with that of pyrazinamide.

\section{Results and Discussion}

We have earlier carried out a series of studies on the properties of substituted pyrazinium salts 5a-c. $^{22,23,44-50}$ It has been shown that they are capable of reacting with various types of nucleophiles under mild conditions to form products of nucleophilic addition to the unsubstituted positions of the pyrazine ring. The aim of the present study is to examine the further modifications of 6-alkoxy adducts 6-8 derived from the reaction of 5-(het)aryl-2,3-dicyano-1ethylpyrazinium tetrafluoroborates 5a-c with O-nucleophiles (water and alcohols) (Scheme 2). ${ }^{23}$

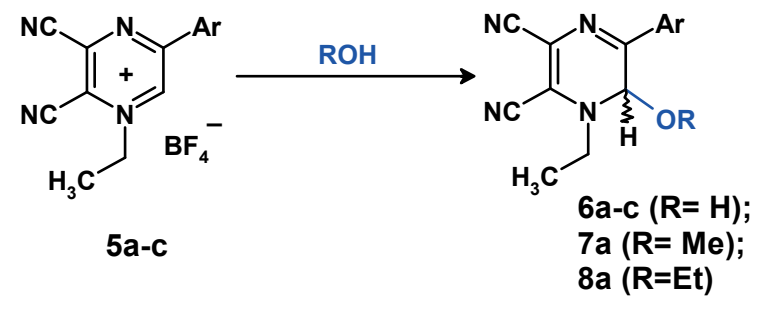

$\operatorname{Ar}=a: P h, \quad b:$ thiophen-2-yl, c: thiophen-3-yl

\section{Scheme 2}

Taking into account a structural analogy between O-adducts 6-8 and amino alcohols 4 derived from the Petasis reaction, we have investigated the reaction of 6-8 with thienylboronic acids. It has been established that the alkoxy adducts 6-8 react readily with 2-thienylboronic 9 and 3-thienylboronic 10 acids under mild conditions $\left(\mathrm{CH}_{2} \mathrm{Cl}_{2}, 20-25{ }^{\circ} \mathrm{C}, 1\right.$ hour $)$ to give 1-ethyl5-(het)aryl-6-thiophen-2-yl-1,6-dihydropyrazine-2,3-dicarbonitriles 11a-c and 1-ethyl-5(het)aryl-6-thiophen-3-yl-1,6-dihydropyrazine-2,3-dicarbonitriles 12a-c (Scheme 3, Table 1). 


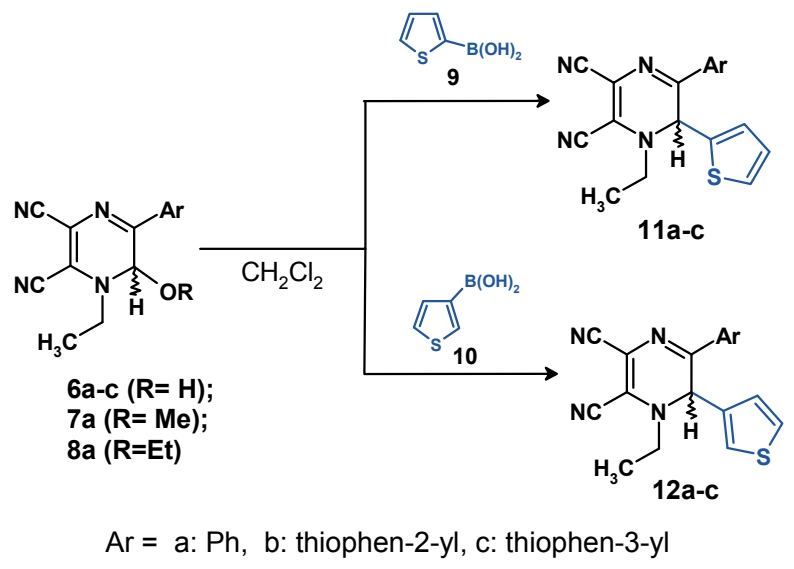

\section{Scheme 3}

In a similar way, the reaction of the hydroxy adducts $\mathbf{6 a - c}$ with benzo[b]thien-2-ylboronic $\mathbf{1 3}$ and benzo[b]thien-3-ylboronic $\mathbf{1 4}$ acids leads to the corresponding 6-benzo[b]thiophen-2-yl-1ethyl-5-(het)aryl-1,6-dihydropyrazine-2,3-dicarbonitriles 15a-c and 6-benzo[b]thiophen-3-yl-1ethyl-5-(het)aryl-1,6-dihydropyrazine-2,3-dicarbonitriles 16a-c in good yields 55-98\% (Scheme 4, Table 1).

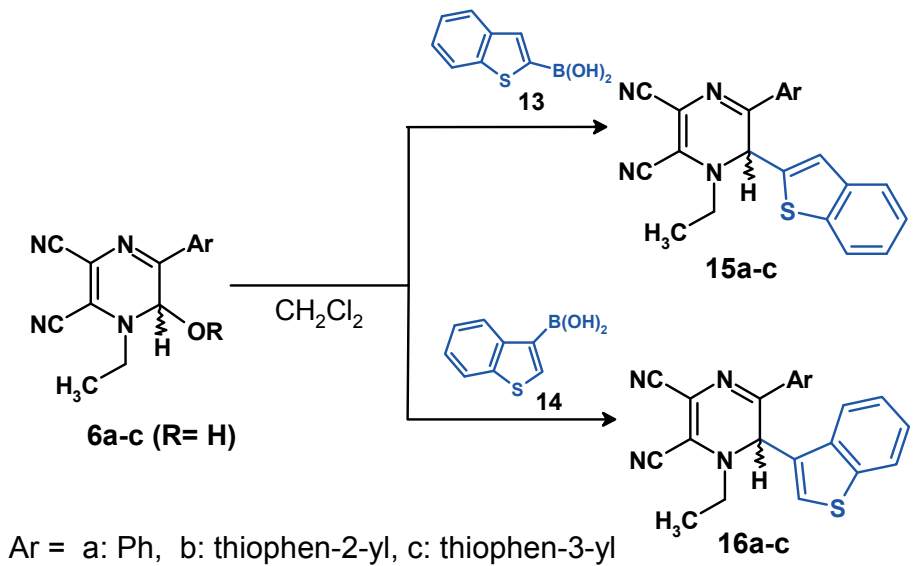

\section{Scheme 4}

On treatment of the adducts 6a-c with 2-furanylboronic acid (17) the corresponding 1-ethyl6-furan-2-yl-5-(het)aryl-1,6-dihydropyrazine-2,3-dicarbonitriles 18a-c were obtained in yields $55-98 \%$ (Scheme 5, Table 1).

The evidence for the structures of all di(hetero)aryl-substituted dihydropyrazines has been obtained by means of ${ }^{1} \mathrm{H}$ and ${ }^{13} \mathrm{C}$ NMR spectroscopy, and X-ray crystallography analysis performed for racemic 1-ethyl-5-phenyl-6-thiophen-2-yl-1,6-dihydropyrazine-2,3-dicarbonitrile (11a), 1-ethyl-5-thiophen-3-yl-6-thiophen-2-yl-1,6-dihydro-pyrazine-2,3-dicarbonitrile (11c) and 1-ethyl-5-phenyl-6-thiophen-3-yl-1,6-dihydropyrazine-2,3-dicarbonitriles (12a) (Figs. 1-3). 


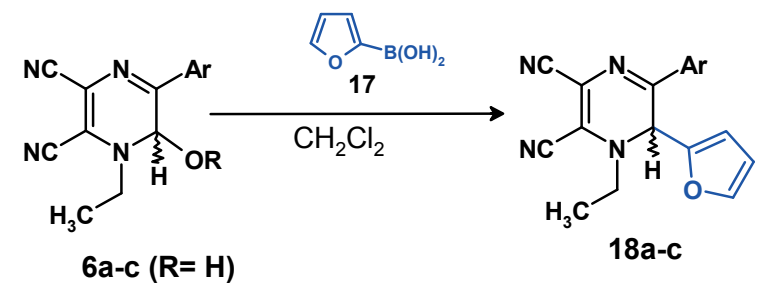

$\operatorname{Ar}=a: P h, \quad b:$ thiophen-2-yl, c: thiophen-3-yl

\section{Scheme 5}

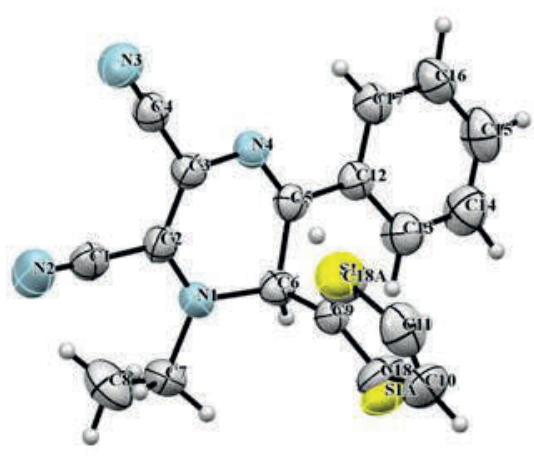

Figure 1. X-ray structure of ( \pm -11a.

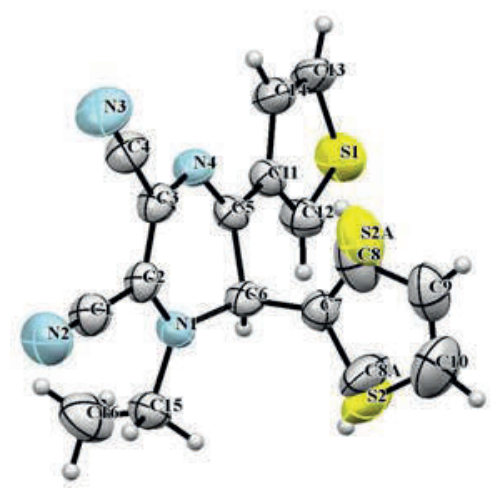

Figure 2. X-ray structure of ( \pm -11c.

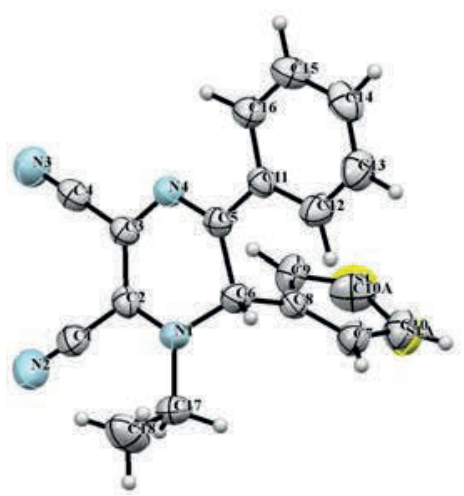

Figure 3. X-ray structure of ( \pm -12a.

In case of highly reactive alkoxy adducts $6 \mathbf{a}, 7 \mathbf{a}$ and $8 \mathbf{a}$ yields of dihydropyrazine 11a are nearly independent of the substituents $\mathrm{R}$ in the alkoxy-group (see entries 1-3).

The reactions of alkoxy adducts $\mathbf{6 a - c}, 7 \mathbf{a}, \mathbf{8 a}$ with $\pi$-rich heteroaromatic boronic acids proved to proceed in good yields (entries 1-17), however phenylboronic acid did not enter the reaction at all due to its low reactivity. ${ }^{51}$ It should be noted that the Petasis type reaction for 1,4-diazines is observed for the first time, although similar transformations have been described earlier for derivatives of quinoline and isoquinoline. ${ }^{51}$

According to the X-ray data, all racemic compounds 11a,c and 12a are crystallized in centrosymmetric $\mathrm{P} 2{ }_{1} / \mathrm{n}$ space group of monoclinic crystal system, and are characterized by the similarity of magnitudes in unit cell parameters (Tables 2, 4). 
Table 1. Reaction conditions and yields of compounds 11, 12, 15, 16 and 18

\begin{tabular}{llllll}
\hline Entry & Reaction & Time, h & Product & $\begin{array}{l}\text { Isolated } \\
\text { yields (\%) }\end{array}$ & $\begin{array}{l}\text { Yield on } \\
\text { GC-MS (\%) }\end{array}$ \\
\hline 1 & $\mathbf{6 a}+\mathbf{9}$ & 1 & $\mathbf{1 1 a}$ & 76 & 97 \\
2 & $\mathbf{7 a}+\mathbf{9}$ & 1 & $\mathbf{1 1 a}$ & n.d. & 98 \\
3 & $\mathbf{8 a}+\mathbf{9}$ & 1 & $\mathbf{1 1 a}$ & n.d. & 97 \\
4 & $\mathbf{6 a}+\mathbf{1 0}$ & 20 & $\mathbf{1 2 a}$ & 57 & n.d. \\
5 & $\mathbf{6 b}+\mathbf{9}$ & 20 & $\mathbf{1 1 b}$ & 68 & n.d. \\
6 & $\mathbf{6 b}+\mathbf{1 0}$ & 20 & $\mathbf{1 2 b}$ & 64 & n.d. \\
7 & $\mathbf{6 c}+\mathbf{9}$ & 20 & $\mathbf{1 1 c}$ & 65 & n.d. \\
8 & $\mathbf{6 c}+\mathbf{1 0}$ & 20 & $\mathbf{1 2 c}$ & 79 & n.d. \\
9 & $\mathbf{6 a}+\mathbf{1 3}$ & 48 & $\mathbf{1 5 a}$ & 55 & n.d. \\
10 & $\mathbf{6 b}+\mathbf{1 3}$ & 17 & $\mathbf{1 5 b}$ & 58 & n.d. \\
11 & $\mathbf{6 c}+\mathbf{1 3}$ & 17 & $\mathbf{1 5 c}$ & 98 & n.d. \\
12 & $\mathbf{6 a}+\mathbf{1 4}$ & 48 & $\mathbf{1 6 a}$ & 59 & n.d. \\
13 & $\mathbf{6 b}+\mathbf{1 4}$ & 17 & $\mathbf{1 6 b}$ & 76 & n.d. \\
14 & $\mathbf{6 c}+\mathbf{1 4}$ & 17 & $\mathbf{1 6 c}$ & 80 & n.d. \\
15 & $\mathbf{6 a}+\mathbf{1 7}$ & 24 & $\mathbf{1 8 a}$ & 75 & n.d. \\
16 & $\mathbf{6 b}+\mathbf{1 7}$ & 24 & $\mathbf{1 8 b}$ & 86 & n.d. \\
17 & $\mathbf{6 c}+\mathbf{1 7}$ & 24 & $\mathbf{1 8 c}$ & 71 & n.d. \\
\hline
\end{tabular}

n.d. - not determined

Table 2. Some stereometric characteristics of dihydropyrazines according to the X-Ray data. A numeration of ring's atoms is given according to the figure below

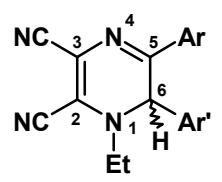

\begin{tabular}{llll}
\hline Compound & $( \pm)-11 \mathrm{a}$ & $( \pm)-11 \mathrm{c}$ & $( \pm)-12 \mathrm{a}$ \\
\hline $\mathrm{d}(\mathrm{C6}-\mathrm{N} 1 \mathrm{C} 2 \mathrm{C} 3 \mathrm{C} 4 \mathrm{C} 5), \AA$. & 0.408 & 0.499 & 0.394 \\
Dihedral angle & 21.47 & 26.75 & 20.37 \\
$\begin{array}{l}\text { C6N1C2C3/C3N4C5C6, deg. } \\
\text { Dihedral angle }\end{array}$ & 27.59 & 33.96 & 26.45 \\
N1C2C3C4C5/C5C6N1, deg. & & & \\
C6-C5, $\AA$ & $1.518(2)$ & $1.517(3)$ & $1.533(3)$ \\
C6-C(Ar'), $\AA$ & $1.5066(19)$ & $1.490(3)$ & $1.499(3)$ \\
C5-C(Ar), $\AA$ & $1.4806(19)$ & $1.455(3)$ & $1.472(3)$ \\
N1-C2, $\AA$ & $1.3456(18)$ & $1.348(3)$ & $1.342(2)$
\end{tabular}


Table 2. Continued

\begin{tabular}{llll}
\hline C6-N1, $\AA$ & $1.4769(18)$ & $1.470(2)$ & $1.472(2)$ \\
Angle C5C6N1, deg. & $109.89(12)$ & $108.82(16)$ & $109.79(18)$ \\
C2-C(N), $\AA$ & $1.446(2)$ & $1.430(3)$ & $1.442(3)$ \\
$\mathrm{C} 3-\mathrm{C}(\mathrm{N}), \AA$ & $1.429(2)$ & $1.431(3)$ & $1.432(3)$ \\
$(\mathrm{C} 2) \mathrm{C} \equiv(\mathrm{N}), \AA$ & $1.1401(18)$ & $1.139(3)$ & $1.133(3)$ \\
$(\mathrm{C} 3) \mathrm{C} \equiv(\mathrm{N}), \AA$ & $1.1431(18)$ & $1.136(3)$ & $1.141(2)$ \\
\hline
\end{tabular}

Low variations in unit cell parameters for these structures are rationalised by the very similar packing requirements of the thiophene and benzene ring substituents in compounds 11a/12a and 11c. The dihydropyrazine ring in compounds is non-planar, the $s p^{3}$-hybridized atom is deviated from the least-squared plane of the ring on 0.4-0.5 $\AA$, and dihedral angles between the planes C6N1C2C3 and C3N4C5C6 are in limits 20-30 (numeration of atoms is given according to the figure for Table 2). However, atoms C3, N4, C5 are placed approximately in the plane of (het)aryl substituent at $\mathrm{C} 5$ and the double $\mathrm{C}=\mathrm{N}$ bond of the azadienic fragment is obviously conjugated with the $\pi$-electronic system of the substituent. Measured sterical parameters of the dihydropyrazinic system, in particular, deviation of the $s p^{3}$-atom from a plane of the pyrazine ring $\mathrm{d}(\mathrm{C} 6-\mathrm{N} 1 \mathrm{C} 2 \mathrm{C} 3 \mathrm{C} 4 \mathrm{C} 5)$, dihedral angles between planes $\mathrm{C} 6 \mathrm{~N} 1 \mathrm{C} 2 \mathrm{C} 3 / \mathrm{C} 3 \mathrm{~N} 4 \mathrm{C} 5 \mathrm{C} 6$ and $\mathrm{N} 1 \mathrm{C} 2 \mathrm{C} 3 \mathrm{C} 4 \mathrm{C} 5 / \mathrm{C} 5 \mathrm{C} 6 \mathrm{~N} 1$, are depending not from the type of substituents at the sp3-hybridised Catom (Ar'), but from effects of the dihydropyrazine azadiene system conjugation with Ar substituent at C5. For pair 11a/12a a good structural correspondence is observed, however at the same time the structural parameters for the pair 11a/11c show significant differences (see Table 2 ). The next structural differences of dihydropyrazines are connected with their conformations and molecular packing. Dihedral angle between the plane of substitient Ar' at the sp3-hybridized $\mathrm{C}$-atom and the plane $\mathrm{C} 5 \mathrm{C} 6 \mathrm{C}\left(\mathrm{Ar}^{\prime}\right)$ for the pair 11a/12a is $\sim 50^{\circ}$, the same angle for compound $11 \mathrm{c}$ is $\sim 20^{\circ}$ (exact definition of magnitudes is not possible due to disordering of substituent $\mathrm{Ar}^{\prime}$ ). Despite on proximity of unit cell parameters, molecular packing for the pair 11a/12a and compound 11c show some variations. In particular, molecular packing for the pair 11a/12a is characterized by the presence of $\pi$-contacts between $\mathrm{C} \equiv \mathrm{N}$-groups and the azadiene system of the dihydropirazinis ring with distance $\sim 3.3 \AA$. This type of interaction is absent in packing of compound 11c, and their molecules form layers parallel $0 \mathrm{~b}$ axe by means of axial N...S type contacts with distances $\sim 3.25 \AA$ between $\mathrm{C} \equiv \mathrm{N}$-groups and $\mathrm{S}$-atoms of thienyl substituent at $\mathrm{C} 5$.

All dihydropyrazines $( \pm)-11,12,15,16$ and 18 were separated as pure enantiomers [enantiomeric excess approximately $95-99.9 \%$ ] by semi-preparative chiral HPLC using Kromasil 5-CelluCoat $(150 \times 4.6 \mathrm{~mm}, 5 \mu \mathrm{m})$ column. Chiral HPLC and polarimetric analysis indicated that for all racemates, the first eluted enantiomers rotated polarized light in the negative direction, accordingly to a similar nature of substituents at the stereogenic center $\mathrm{C}(6)$. Crystals of enantiomeric pairs $\boldsymbol{R}-(-)-\mathbf{1 1 b} / \boldsymbol{S}-(+)-11 b$ and $\boldsymbol{R}-(-)-11 c / S-(+)-11 c$ suitable for X-ray experiments were grown by crystallization from acetonitrile solution. Enantiomeres $\boldsymbol{R}-(-)-\mathbf{1 1 b} / \boldsymbol{S}$ $(+)-11 b$ and $\boldsymbol{R}-(-)-11 c / S-(+)-11 c$ were crystallized in very typical chiral P $2{ }_{1}{ }_{1}{ }_{2}{ }_{1}$ space group of 
orthorhombic crystal system with the nearest magnitudes in unit cell parameters (Tables 5, Figs. 4 and 5). All deviations in magnitudes in unit cell parameters for the pair of enantiomeres can to be explained by variation in temperatures of experiments and experimental errors. The presence of sulfur atoms in their structures permits to establish an absolute configuration of compounds. The absolute configuration of compounds was established on the basis of anomalous scattering effect (by Flack parameters), however, only for the $\boldsymbol{R}-(-)-11 b$ and $S-(+)-11 c$ isomers their parameters are significant (Table 5). For the isomers $\boldsymbol{R}-(+)-\mathbf{1 1 b}$ and $\boldsymbol{S}-(-)-11 c$ their parameters are less than the measurement mistakes, but are in accordance with measurements for enantiopodes. General stereochemistry of the enantiomeres is in good agreement with the stereochemistry of racemates. Some variations in dihedral angles due to rotation of a substituent around the single C-C bond's axis can to be explained by changing in the molecular packing environment. Any shortened intermolecular contacts in the molecular packing are absent.

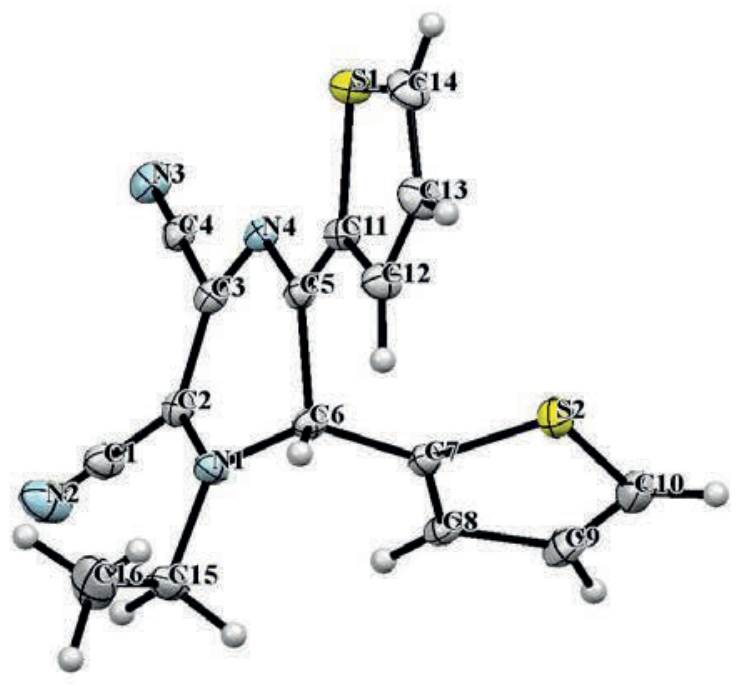

Figure 4. X-ray structure of enantiomer R-(-)-11b.

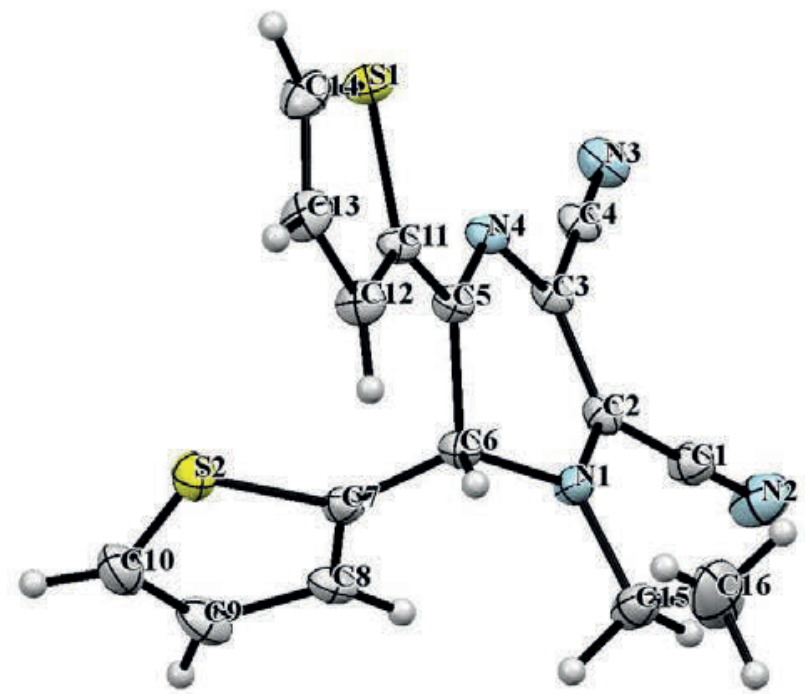

Figure 5. X-ray structure of enantiomer $S-(+)-11 b$.

On the basis of combined chromatographic and X-ray studies, the absolute configuration assignment was unambiguously completed, and configurations were assigned to the fifteen enantiomeric pairs: $R-(-)-11 a-c, 12 a-c, 15 a-c, 16 a-c, 18 a-c / S-(+)-11 a-c, 12 a-c, 15 a-c, 16 a-c$, 18a-c. Due to comparable chiral centers in this group of molecules, the results clearly indicate at the $(S)$-absolute configuration for all dextrorotatory enantiomers of the series and at the $(R)$ absolute configuration for the corresponding levorotatory isomers.

The antimycobacterial activity of compounds 11, 12, 15, 16 and 18 was tested against $M$. tuberculosis $\mathrm{H}_{37} \mathrm{Rv}$, avium, terrae and extensively drug-resistant and multi-drug-resistant strains. All new dihydropyrazines were compared with the commercially available drugs Isoniazid and Pyrazineamide under the same experimental conditions (Table 3). 
Table 3. Antimycobacterial activity of 1,6-dihydropyrazines

\begin{tabular}{|c|c|c|c|c|c|c|}
\hline \multirow[t]{2}{*}{ Entry } & \multirow[t]{2}{*}{ Compound } & \multicolumn{5}{|c|}{$\begin{array}{l}\text { Antimycobacterial activity against different strains } \\
\text { of Mycobacterium tuberculosis (MIC in } \mu \mathrm{g} / \mathrm{mL} \text { ) }\end{array}$} \\
\hline & & $\mathrm{H}_{37} \mathrm{Rv}$ & M. avium & M. terrae & MDR & XDR \\
\hline 1 & $R-(-)-11 \mathrm{a}$ & 6.2 & 6.2 & 6.2 & 6.2 & 6.2 \\
\hline 2 & $S-(+)-11 \mathrm{a}$ & 6.2 & 6.2 & 6.2 & 6.2 & 6.2 \\
\hline 3 & $R-(-)-11 b$ & 6.2 & 6.2 & 6.2 & 6.2 & 6.2 \\
\hline 4 & $S-(+)-11 \mathrm{~b}$ & 6.2 & 6.2 & 6.2 & 6.2 & 6.2 \\
\hline 5 & $R-(-)-11 \mathrm{c}$ & 6.2 & 3.1 & 3.1 & 6.2 & 6.2 \\
\hline 6 & $S-(+)-11 c$ & 6.2 & 6.2 & 6.2 & 6.2 & 6.2 \\
\hline 7 & $R-(-)-12 a$ & 1.5 & 0.75 & 0.75 & 1.5 & 1.5 \\
\hline 8 & $S-(+)-12 \mathrm{a}$ & 3.1 & 3.1 & 1.5 & 3.1 & 3.1 \\
\hline 9 & $R-(-)-12 b$ & 0.75 & 0.3 & 0.3 & 0.75 & 0.75 \\
\hline 10 & $S-(+)-12 b$ & 1.5 & 0.75 & 0.75 & 1.5 & 1.5 \\
\hline 11 & $R-(-)-12 \mathrm{c}$ & 6.2 & 6.2 & 6.2 & 6.2 & 6.2 \\
\hline 12 & $S-(+)-12 c$ & 6.2 & 6.2 & 6.2 & 6.2 & 6.2 \\
\hline 13 & $R-(-)-15 a$ & 12.5 & 12.5 & 12.5 & 12.5 & 12.5 \\
\hline 14 & $S-(+)-15 a$ & 12.5 & 12.5 & 12.5 & 12.5 & 12.5 \\
\hline 15 & $R-(-)-15 b$ & 12.5 & 12.5 & 12.5 & 12.5 & 12.5 \\
\hline 16 & $S-(+)-15 b$ & 12.5 & 12.5 & 12.5 & 12.5 & 12.5 \\
\hline 17 & $R-(-)-15 \mathrm{c}$ & 12.5 & 12.5 & 12.5 & 12.5 & 12.5 \\
\hline 18 & $S-(+)-15 \mathrm{c}$ & 12.5 & 12.5 & 12.5 & 12.5 & 12.5 \\
\hline 19 & $R-(-)-16 a$ & 12.5 & 12.5 & 12.5 & 12.5 & 12.5 \\
\hline 20 & $S-(+)-16 \mathrm{a}$ & 12.5 & 12.5 & 12.5 & 12.5 & 12.5 \\
\hline 21 & $R-(-)-16 b$ & 1.5 & 0.75 & 0.75 & 1.5 & 1.5 \\
\hline 22 & $S-(+)-16 b$ & 12.5 & 12.5 & 12.5 & 12.5 & 12.5 \\
\hline 23 & $R-(-)-16 \mathrm{c}$ & 1.5 & 0.75 & 0.75 & 1.5 & 1.5 \\
\hline 24 & $S-(+)-16 \mathrm{c}$ & 6.2 & 6.2 & 6.2 & 6.2 & 6.2 \\
\hline 25 & $R-(-)-18 \mathrm{a}$ & 12.5 & 12.5 & 12.5 & 12.5 & 12.5 \\
\hline 26 & $S-(+)-18 \mathrm{a}$ & 12.5 & 12.5 & 12.5 & 12.5 & 12.5 \\
\hline 27 & $R-(-)-18 b$ & 0.75 & 0.3 & 0.3 & 0.75 & 0.75 \\
\hline 28 & $S-(+)-18 b$ & 12.5 & 12.5 & 12.5 & 12.5 & 12.5 \\
\hline 29 & $R-(-)-18 c$ & 12.5 & 12.5 & 12.5 & 12.5 & 12.5 \\
\hline \multirow[t]{3}{*}{30} & $S-(+)-18 \mathrm{c}$ & 12.5 & 12.5 & 12.5 & 12.5 & 12.5 \\
\hline & Pyrazinamide & 12.5 & n.d. & n.d. & - & - \\
\hline & Isoniazid & 0.1 & 0.1 & 0.1 & - & - \\
\hline
\end{tabular}

n.d. - not determined; MDR (multi-drug-resistant tuberculosis strain) - Rifampin and isoniazid resistant Mycobacterium tuberculosis strain having Beijing genotype with a combination of 
mutations Ser 531 - Leu 315 and Ser-Thr in rpoB and katG genes, respectively; XDR extensively drug-resistant tuberculosis strain.

It has been established that the most active compounds of the series contain thiophenyl groups, while a low activity was found for the phenyl-substituted dihydropyrazines. Compounds, bearing 3-thiophenyl 12a,b and 3-benzo[b]thiophenyl 16b,c fragments at $\mathrm{C}(6)$ position of the dihydropyrazine ring, were highly antimicobactrial and inhibited $M$. tuberculosis growth at concentration of $0.75-1.5 \mu \mathrm{g} / \mathrm{mL}$. Incorporation of 2-thiophenyl 11a-c group at $\mathrm{C}(6)$ position of the dihydropyrazine ring resulted in a slightly less activity (MIC $6.2 \mu \mathrm{g} / \mathrm{mL}$ ). In contrast, introduction of other groups, such as 2-benzo[b]thiophenyl (15a-c) or 2-furyl (18a,c), resulted in rather poor activity (MIC $12.5 \mu \mathrm{g} / \mathrm{mL}$ ). Furthermore, the most active compounds exhibited enantiomer selectivity, generally preferring the $R$-(-)-forms over the $S$-(+)-enantiomers, as demonstrated by the data for compounds $R-(-)-\mathbf{1 2 a}, \boldsymbol{R}-(-)-\mathbf{1 2 b}, \boldsymbol{R}-(-)-\mathbf{1 6 b}, \boldsymbol{R}-(-)-\mathbf{1 6 c}$ and $\boldsymbol{R}-(-)-$ $\mathbf{1 8 b}$ (see Table 3).

The results obtained show that antimycobacterial activity of several derivatives of the series of 1-alkyl-2,3-dicyano-5-aryl-6-hetaryl-1,6-dihydropyrazines is similar to the standard drugs. In addition, the compounds of this series are active against extensively drug-resistant and multidrug-resistant strains of Mycobacterium tuberculosis.

\section{Conclusions}

It has been shown that the Petasis reaction provides a mild, practical, and novel method for noncatalytic synthesis of dihydropyrazine derivatives. Novel 1-alkyl-2,3-dicyano-5-(het)aryl-6hetaryl-1,6-dihydropyrazines have been obtained and characterized. The structures of these compounds have been established by X-ray crystallography analysis. Several compounds of this series proved to possess a better antimycobacterial activity, than those from the family of classic antituberculosis drugs, for example Pyrazinamide. Indeed, 6-thienyl and 6-furyl substituted 1alkyl-2,3-dicyano-5-(het)aryl-6-hetaryl-1,6-dihydropyrazines can be regarded as promising candidates for the further development of antitubercular agents.

\section{Experimental Section}

General. All solvents and reagents were purified and prepared according to the literature data. ${ }^{52}$ Compounds 6-8 were synthesized according to the procedures described in the literature. ${ }^{23}{ }^{1} \mathrm{H}$ and ${ }^{13} \mathrm{C}$ NMR spectra were recorded on a Bruker AVANCE-500 instrument using $\mathrm{Me}_{4} \mathrm{Si}$ as an internal standard. All signals in the ${ }^{1} \mathrm{H}$ and ${ }^{13} \mathrm{C}$ NMR spectra were assigned on the basis of 2D ${ }^{1} \mathrm{H}-{ }^{1} \mathrm{H}$ COSY, ${ }^{1} \mathrm{H}-{ }^{13} \mathrm{C}$ HSQC and HMBC experiments. Elemental analysis was carried on a Eurovector EA 3000 automated analyzer. Melting points were determined on Boetius combined 
heating stages and were not corrected. The GC-MS analysis of all samples was carried out using an Agilent GC 7890A MS 5975C Inert XL EI/CI GC-MS spectrometer with a quadrupole massspectrometric detector with electron ionization $(70 \mathrm{eV})$ and scan over the total ionic current in the range $\mathrm{m} / \mathrm{z} 20-1000$ and a quartz capillary column HP-5MS $(30 \mathrm{~m} \times 0.25 \mathrm{~mm}$, film thickness $0.25 \mathrm{~mm}$ ). Helium was used as a carrier gas, the split ratio of the flow was $1: 50$, and the consumption through the column was $1.0 \mathrm{~mL} \mathrm{~min}^{-1}$; the initial temperature of the column was 40 ${ }^{\circ} \mathrm{C}$ (storage $3 \mathrm{~min}$ ), programming rate was $10{ }^{\circ} \mathrm{C} \mathrm{min}^{-1}$ to $290{ }^{\circ} \mathrm{C}$ (storage $20 \mathrm{~min}$ ), the temperature of the evaporator was $250{ }^{\circ} \mathrm{C}$, the temperature of the source was $230{ }^{\circ} \mathrm{C}$, the temperature of the quadrupole was $150{ }^{\circ} \mathrm{C}$, and the temperature of the transition chamber was $280{ }^{\circ} \mathrm{C}$. Solutions of the samples with a concentration of $3-4 \mathrm{mg} \mathrm{mL}{ }^{-1}$ were prepared in acetonitrile. Samples of $1 \mathrm{~mL}$ of the obtained solutions were analyzed. Column chromatography was carried out using Lancaster silica gel 0.040-0.063 mm (230-400 mesh), eluting with ethyl acetate-hexane, $1: 2$. The progress of reactions and the purity of compounds were checked by TLC on Sorbfil plates (Russia), in which the spots were visualized with UV light ( $\lambda 254$ or 365 $\mathrm{nm})$.

Microwave experiments were carried out in a Discover unimodal microwave system (CEM, USA) with a working frequency of $2.45 \mathrm{GHz}$ and the power of microwave radiation ranged from 0 to $300 \mathrm{~W}$. The reactions were carried out in a $10 \mathrm{~mL}$ reaction tube with the hermetic Teflon cork. The temperature of the reaction was monitored using an inserted IR sensor by the external surface of the reaction vessel.

Semi-preparative HPLC enantioseparations were performed on an Agilent 1100 instrument using stainless-steel Kromasil 5-CelluCoat $(150 \times 4.6 \mathrm{~mm}, 5 \mu \mathrm{m})$ column. The analytical HPLC to determine the enantiomeric excess of the optically pure compounds was performed on the same instrument using chiral Kromasil CelluCoat $(150 \times 4.6 \mathrm{~mm}, 5 \mu \mathrm{m})$ column and mobile phase of $\mathrm{CH}_{3} \mathrm{CN}-\mathrm{H}_{2} \mathrm{O}$ at the different ratio. The values of retention time $\left(t_{\mathrm{R}}\right)$ were given in minutes. Enantiomeric excess values were calculated from peak areas using the formula (A1$\mathrm{A} 2) /(\mathrm{A} 1+\mathrm{A} 2)$, where $\mathrm{A} 1$ is the major enantiomer. Specific rotations of enantiomers were measured at $589 \mathrm{~nm}$ with a Perkin-Elmer polarimeter model 341 equipped with a Na lamp. The volume of the cell was $1 \mathrm{~mL}$, and the optical path was $10 \mathrm{~cm}$. A standard solution was prepared

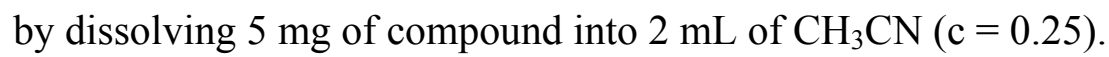

X-ray diffraction analysis of single crystals of 11a,c, 12a and $\boldsymbol{R}-(-)-11 c$ was performed on an automated X-ray diffractometer "Xcalibur 3" equipped with CCD detector. Compounds $\boldsymbol{R}-(-)-$ 11b, $S$-(+)-11b, $S$-(+)-11c were analyzed on an automated X-ray diffractometer "Xcalibur E" on a standard procedure $\left(\lambda \mathrm{MoK}_{\alpha}\right.$, graphite monochomator, $\omega / 2 \theta$ scanning with step $\left.1^{\circ}\right)$. Empirical absorption correction was performed. Structures of compounds 11a,c, 12a and $\boldsymbol{R}-(-)-11 c$ were solved and refined by full-matrix least-squared method on $\mathrm{F}^{2}$ with using SHELXTL program package. ${ }^{53}$ Compounds $\boldsymbol{R}-(-)-11 b, S-(+)-11 b, S-(+)-11 c$ were solved and refined by using Olex2 program. ${ }^{54}$ Non hydrogen atoms were refined in anisotropic approximation; H-atoms were refined in isotropic approximation in riding model. General X-Ray data are summarized in the Table 4. The X-ray crystallography data for structures 11a-c and 12a reported in this paper have 
been deposited with Cambridge Crystallography Data Centre as supplementary publications no CCDC 991536 for $( \pm)-11 a$, CCDC 991537 for $( \pm)-11 c$, CCDC 991538 for $( \pm)-12 a$, CCDC 991532 for (+)-11b, CCDC 991533 for (-)-11b, CCDC 991534 for (+)-11c and CCDC 991535 for (-)-11c. These data can be obtained free of charge from the Cambridge Crystallographic Data Centre via $w w w . c c d c . c a m . a c . u k / d a t a$ request/cif.

Table 4. General X-ray structural data for racemic compounds 11a,c and 12a

\begin{tabular}{|c|c|c|c|}
\hline Compound & $11 \mathrm{a}$ & $11 \mathrm{c}$ & $12 \mathbf{a}$ \\
\hline Crystal size, $\mathrm{mm}$ & $0.25 \times 0.20 \times 0.15$ & $0.25 \times 0.20 \times 0.15$ & $0.25 \times 0.20 \times 0.15$ \\
\hline Crystal color & Orange & orange & orange \\
\hline Empirical formula & $\mathrm{C}_{18} \mathrm{H}_{14} \mathrm{~N}_{4} \mathrm{~S}$ & $\mathrm{C}_{16} \mathrm{H}_{12} \mathrm{~N}_{4} \mathrm{~S}_{2}$ & $\mathrm{C}_{18} \mathrm{H}_{14} \mathrm{~N}_{4} \mathrm{~S}$ \\
\hline Temperature, $\mathrm{K}$ & $295(2)$ & $295(2)$ & $295(2)$ \\
\hline Crystal system & Monoclinic & Monoclinic & Monoclinic \\
\hline Space group & $\mathrm{P} 2{ }_{1} / \mathrm{n}$ & $\mathrm{P} 2{ }_{1} / \mathrm{n}$ & $\mathrm{P} 2{ }_{1} / \mathrm{n}$ \\
\hline $\mathrm{a}, \AA$ & $10.1483(9)$ & $8.1995(7)$ & $10.1126(17)$ \\
\hline $\mathrm{b}, \AA$ & $16.0775(16)$ & $16.8758(15)$ & $15.9301(14)$ \\
\hline $\mathrm{c}, \AA$ & $10.3350(10)$ & $12.2379(9)$ & $10.2752(13)$ \\
\hline$\alpha$ & 90 & 90 & 90 \\
\hline$\beta$ & $107.086(8)$ & $108.675(7)$ & $107.097(13)$ \\
\hline$\gamma$ & 90 & 90 & 90 \\
\hline Volume $(\AA), Z$ & $1611.8(3), 4$ & $1604.2(2), 4$ & $1582.1(4), 4$ \\
\hline$\mu, \mathrm{mm}^{-1}$ & 0.205 & 0.333 & 0.209 \\
\hline $\begin{array}{l}\text { Reflections } \\
\text { collected }\end{array}$ & 10204 & 8088 & 5918 \\
\hline Independent & 3958 & 3862 & $3157(0.0311)$ \\
\hline reflections $\left(\mathrm{R}_{\text {int }}\right)$ & $(0.0291)$ & $(0.0219)$ & \\
\hline $\begin{array}{l}\text { Reflections } \\
\text { with } I>2 \sigma(I)\end{array}$ & 1615 & 1860 & 1354 \\
\hline GooF & 1.002 & 0.990 & 1.002 \\
\hline $\mathrm{R}_{1}[\mathrm{I}>2 \sigma(\mathrm{I})]$ & 0.0348 & 0.0455 & 0.0362 \\
\hline $\mathrm{wR}_{2}[\mathrm{I}>2 \sigma(\mathrm{I})]$ & 0.0710 & 0.1231 & 0.0492 \\
\hline $\mathrm{R}_{1}$ (all data) & 0.0995 & 0.0946 & 0.0951 \\
\hline $\mathrm{wR}_{2}$ (all data) & 0.0748 & 0.1334 & 0.0512 \\
\hline $\begin{array}{l}\text { Largest diff. } \\
\text { peak and hole, } \overline{\mathrm{e}} / \AA^{3}\end{array}$ & $0.145 /-0.220$ & $0.258 /-0.300$ & $0.167 /-0.237$ \\
\hline Completeness & $98.9 \%$ & $98.8 \%$ & $97.5 \%$ \\
\hline to $\theta$ (deg.) & $(28.28)$ & $(26.00)$ & $(26.38)$ \\
\hline
\end{tabular}


Table 5. General X-ray structural data for enantiomeric compounds $R-(-)-\mathbf{1 1 b} / S-(+)-\mathbf{1 1 b}$ and $R-$ $(-)-11 \mathrm{c} / S-(+)-11 \mathrm{c}$

\begin{tabular}{|c|c|c|c|c|}
\hline Compound & $R-(-)-11 \mathrm{~b}$ & $S-(+)-11 \mathrm{~b}$ & $R-(-)-11 \mathrm{c}$ & $S-(+)-11 \mathrm{c}$ \\
\hline Crystal size, $\mathrm{mm}$ & $0.26 \times 0.21 \times 0.17$ & $0.23 \times 0.17 \times 0.08$ & $0.30 \times 0.25 \times 0.20$ & $0.25 \times 0.2 \times 0.15$ \\
\hline Crystal color & orange & orange & orange & orange \\
\hline Empirical formula & $\mathrm{C}_{16} \mathrm{H}_{12} \mathrm{~N}_{4} \mathrm{~S}_{2}$ & $\mathrm{C}_{16} \mathrm{H}_{12} \mathrm{~N}_{4} \mathrm{~S}_{2}$ & $\mathrm{C}_{16} \mathrm{H}_{12} \mathrm{~N}_{4} \mathrm{~S}_{2}$ & $\mathrm{C}_{16} \mathrm{H}_{12} \mathrm{~N}_{4} \mathrm{~S}_{2}$ \\
\hline Temperature, K & $120.00(10)$ & $150.0(1)$ & $295(2)$ & 149.91(18) \\
\hline Crystal system & orthorhombic & orthorhombic & orthorhombic & orthorhombic \\
\hline Space group & $\mathrm{P} 2{ }_{1} 2_{1} 2_{1}$ & $\mathrm{P} 2{ }_{1} 2_{1} 2_{1}$ & $\mathrm{P} 2{ }_{1}{ }_{1} 2_{1}$ & $\mathrm{P} 2{ }_{1} 2_{1} 2_{1}$ \\
\hline $\mathrm{a}, \AA$ & $7.2966(3)$ & $7.30865(17)$ & $7.3139(10)$ & $7.24218(12)$ \\
\hline $\mathrm{b}, \AA$ & $12.5764(5)$ & $12.6253(4)$ & $12.8680(6)$ & $12.7486(2)$ \\
\hline $\mathrm{c}, \AA$ & $17.2086(7)$ & $17.2173(4)$ & $17.0494(18)$ & $17.0675(3)$ \\
\hline$\alpha$ & 90 & 90.00 & 90.00 & 90.00 \\
\hline$\beta$ & 90 & 90.00 & 90.00 & 90.00 \\
\hline$\gamma$ & 90 & 90.00 & 90.00 & 90.00 \\
\hline Volume (Å), Z & $1579.15(11)$ & 1588.71(7), 4 & 1604.6(3), 4 & $1575.80(4), 4$ \\
\hline$\mu, \mathrm{mm}^{-1}$ & 0.338 & 0.336 & 0.333 & 0.339 \\
\hline $\begin{array}{l}\text { Reflections } \\
\text { collected }\end{array}$ & 9187 & 7269 & 11930 & 10783 \\
\hline $\begin{array}{l}\text { Independent } \\
\text { reflections }\left(\mathrm{R}_{\text {int }}\right)\end{array}$ & $5200(0.0295)$ & $4330(0.0237)$ & $3981(0.0376)$ & $6291(0.0196)$ \\
\hline $\begin{array}{l}\text { Reflections } \\
\text { with } I>2 \sigma(I)\end{array}$ & 4745 & 3980 & 1748 & 5655 \\
\hline GooF & 1.002 & 1.219 & 1.000 & 1.001 \\
\hline $\mathrm{R}_{1}[\mathrm{I}>2 \sigma(\mathrm{I})]$ & 0.0392 & 0.0369 & 0.0472 & 0.0386 \\
\hline $\mathrm{wR}_{2}[\mathrm{I}>2 \sigma(\mathrm{I})]$ & - & 0.0905 & 0.0906 & 0.1084 \\
\hline $\mathrm{R}_{1}$ (all data) & 0.0458 & 0.0425 & 0.1053 & 0.0457 \\
\hline$w R_{2}$ (all data) & 0.1021 & 0.1009 & 0.0945 & 0.1173 \\
\hline $\begin{array}{l}\text { Largest diff. } \\
\text { peak and hole, } \overline{\mathrm{e}} / \AA^{3}\end{array}$ & $0.59 /-0.28$ & $0.46 /-0.33$ & $0.342 /-206$ & $0.47 /-0.35$ \\
\hline Flack parameter & & & $0.06(9)$ & $0.07(6)$ \\
\hline $\begin{array}{l}\text { Completeness } \\
\text { to } \theta \text { (deg.) }\end{array}$ & & & $99.9 \%(28.30)$ & $99.80 \%(33.07)$ \\
\hline
\end{tabular}


General procedure for the synthesis of 5,6-disubstituted 1,6-dihydropyrazine derivatives $(\mathbf{1 1 , 1 2 , 1 5 , 1 6}$ and 18). A mixture of compound 6 (7 or 8$)(0.5 \mathrm{mmol})$ and hetero(aryl)boronic (2thienylboronic, 3-thienylboronic, benzo[b]thien-2-ylboronic, benzo[b]thien-3-ylboronic or 2-

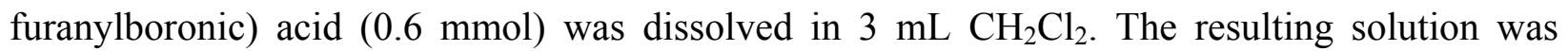
stirred for an appropriate time (see Table 1) at room temperature, the solvent was distilled off in vacuo, and the residue was purified by flash column chromatography (hexane/ethyl acetate) to afford the desired di(hetero)aryl-substituted dihydropyrazine derivatives 11, 12, 15, 16 and 18 .

1-Ethyl-5-phenyl-6-thiophen-2-yl-1,6-dihydropyrazine-2,3-dicarbonitrile (11a). Yield of the racemate (see Table 1, entries 1-3), yellow-orange powder, mp 135-137 ${ }^{\circ} \mathrm{C}$. Racemate was separated by chiral HPLC with a Kromasil 5-CelluCoat $(150 \times 4.6 \mathrm{~mm}, 5 \mu \mathrm{m})$ column. The eluent mixture $\mathrm{CH}_{3} \mathrm{CN}-\mathrm{H}_{2} \mathrm{O} 65: 35$ was used in isocratic mode $\left(0.6 \mathrm{~mL} / \mathrm{min}\right.$ at $\left.25{ }^{\circ} \mathrm{C}\right)$, and the UV signal was monitored at $\lambda 268 \mathrm{~nm}$ to obtain the resolved enantiomeric pair $\boldsymbol{R}-(-)-11 a / S-(-)-$ 11a $\left(t_{\mathrm{R}} 7.37, t_{\mathrm{R}} 11.00\right) . \boldsymbol{R}-(-)-11 \mathrm{a}:[\alpha]_{\mathrm{D}}{ }^{20}-968\left(\mathrm{c} 0.25, \mathrm{CH}_{3} \mathrm{CN}\right)$, ee 98.7\% (Kromasil 5-CelluCoat, $\left.\mathrm{CH}_{3} \mathrm{CN}-\mathrm{H}_{2} \mathrm{O} 70: 30, t_{\mathrm{R}} 3.93\right)$; $\boldsymbol{S}$-(+)-11a: $[\alpha]_{\mathrm{D}}{ }^{20}+877$ (c $0.25, \mathrm{CH}_{3} \mathrm{CN}$ ), ee $97.4 \%$ (Kromasil 5CelluCoat, $\left.\mathrm{CH}_{3} \mathrm{CN}-\mathrm{H}_{2} \mathrm{O} 70: 30, t_{\mathrm{R}} 5.48 \mathrm{~min}\right) . \delta_{\mathrm{H}}\left(500 \mathrm{MHz}, \mathrm{CDCl}_{3}\right) 1.34\left(\mathrm{t}, 3 \mathrm{H}, \mathrm{CH}_{3}, J 7.2 \mathrm{~Hz}\right)$, $3.71\left(\mathrm{dq}, 1 \mathrm{H}, \mathrm{NCH}^{\mathrm{B}}, J 14.5,7.2 \mathrm{~Hz}\right), 3.76\left(\mathrm{dq}, 1 \mathrm{H}, \mathrm{NCH}^{\mathrm{A}}, J 14.5,7.2 \mathrm{~Hz}\right), 5.96(\mathrm{~s}, 1 \mathrm{H}, \mathrm{H} 6), 6.92$ (dt, 1H, H3', J 3.6, 1.0 Hz), 6.96 (dd, 1H, H4', J 5.1, 3.6 Hz), 7.33 (dd, 1H, H5', J 5.1, $1.2 \mathrm{~Hz}$ ), $7.44\left(\mathrm{~m}, 2 \mathrm{H}, \mathrm{Hm}\right.$;), $7.49(\mathrm{~m}, 1 \mathrm{H}, \mathrm{Hp}), 7.90(\mathrm{~m}, 2 \mathrm{H}, \mathrm{Ho}) . \delta_{\mathrm{C}}\left(126 \mathrm{MHz}, \mathrm{CDCl}_{3}\right) 14.97\left(\mathrm{CH}_{3}\right)$, $48.33\left(\mathrm{NCH}_{2}\right), 52.36(\mathrm{C} 6), 110.47(\mathrm{CN}), 111.31(\mathrm{CN}), 115.99(\mathrm{C} 3), 118.24(\mathrm{C} 2), 127.39\left(\mathrm{C5}^{\prime}\right)$, 127.45 (C4'), 127.59 (C3'), 127.97 (Co), $129.01(\mathrm{Cm}), 131.93$ (Cp), $133.70(\mathrm{Ci}), 136.68$ (C2'), 147.37 (C5). GC t $28.85 \mathrm{~min} ; \mathrm{MS} \mathrm{m} / \mathrm{z}$ (rel intensity) $318\left(\mathrm{M}^{+}, 100\right)$. Calcd. for $\mathrm{C}_{18} \mathrm{H}_{14} \mathrm{~N}_{4} \mathrm{~S}$ (318.40): C 67.90, H 4.43, N 17.60. Found C 68.30, H 4.50, N 17.85.

1-Ethyl-5,6-dithiophen-2-yl-1,6-dihydropyrazine-2,3-dicarbonitrile (11b). Yield of the racemate (see Table 1, entry 5), orange powder, mp 124-126 ${ }^{\circ} \mathrm{C}$. Racemate was separated by chiral HPLC with a Kromasil 5-CelluCoat $(150 \times 4.6 \mathrm{~mm}, 5 \mu \mathrm{m})$ column. The eluent mixture $\mathrm{CH}_{3} \mathrm{CN}-\mathrm{H}_{2} \mathrm{O} 75: 25$ was used in isocratic mode $\left(20 \mathrm{~mL} / \mathrm{min}\right.$ at $\left.25^{\circ} \mathrm{C}\right)$, and the UV signal was monitored at $\lambda 280 \mathrm{~nm}$ to obtain the resolved enantiomeric pair $\boldsymbol{R}-(-)-\mathbf{1 1 b} / \boldsymbol{S}-(-)-11 \mathbf{b}\left(t_{\mathrm{R}} 2.92, t_{\mathrm{R}}\right.$ 3.46). $\boldsymbol{R}$-(-)-11b: $[\alpha]_{\mathrm{D}}{ }^{20}-1673$ (c $0.25, \mathrm{CH}_{3} \mathrm{CN}$ ), ee $99.9 \%$ (Kromasil 5-CelluCoat, $\mathrm{CH}_{3} \mathrm{CN}-\mathrm{H}_{2} \mathrm{O}$ 70:30, $t_{\mathrm{R}}$ 5.10); $\boldsymbol{S}-(+)-11 \mathrm{~b}:[\alpha]_{\mathrm{D}}{ }^{20}+1603\left(\mathrm{c} 0.25, \mathrm{CH}_{3} \mathrm{CN}\right.$ ), ee 93.5\% (Kromasil 5-CelluCoat, $\left.\mathrm{CH}_{3} \mathrm{CN}-\mathrm{H}_{2} \mathrm{O} 70: 30, t_{\mathrm{R}} 6.32\right) . \delta_{\mathrm{H}}\left(500 \mathrm{MHz}, \mathrm{CDCl}_{3}\right) 1.34\left(\mathrm{t}, 3 \mathrm{H}, \mathrm{CH}_{3}, J 7.2 \mathrm{~Hz}\right), 3.68(\mathrm{dq}, 1 \mathrm{H}$, $\left.\mathrm{NCH}^{\mathrm{B}}, J 14.5,7.2 \mathrm{~Hz}\right), 3.73\left(\mathrm{dq}, 1 \mathrm{H}, \mathrm{NCH}^{\mathrm{A}}, J 14.5,7.2 \mathrm{~Hz}\right), 5.88(\mathrm{~s}, 1 \mathrm{H}, \mathrm{H6}), 6.95-6.97(\mathrm{~m}, 2 \mathrm{H}$, H3' and H4'), 7.09 (dd, 1H, H4", J 5.1, 3.8 Hz), 7.31 (m, 1H, H5'), 7.47 (dd, 1H, H3", J 3.8, 1.1 $\mathrm{Hz}), 7.56(\mathrm{dd}, 1 \mathrm{H}, \mathrm{H} 5 ", J 5.1,1.1 \mathrm{~Hz}) . \delta_{\mathrm{C}}\left(126 \mathrm{MHz}, \mathrm{CDCl}_{3}\right) 14.72\left(\mathrm{CH}_{3}\right), 48.27\left(\mathrm{NCH}_{2}\right), 53.39$ (C6), $110.18(\mathrm{CN}), 111.34(\mathrm{CN}), 115.84(\mathrm{C} 3), 118.21(\mathrm{C} 2), 127.21,127.28$ and 127.41 (C3', C4' and C5'), 128.25 (C4"), 129.88 (C3"), 132.99 (C5"), 136.97 (C2'), 140.40 (C2"), 143.26 (C5). $\mathrm{GC} \mathrm{t}_{R} 29.38 \mathrm{~min} ; \mathrm{MS} \mathrm{m} / \mathrm{z}$ (rel intensity) $324\left(\mathrm{M}^{+}, 100\right)$. Calcd. for $\mathrm{C}_{16} \mathrm{H}_{12} \mathrm{~N}_{4} \mathrm{~S}_{2}$ (324.43): C 59.24, H 3.73, N 17.27, S 19.77. Found C 59.42, H 3.65, N 16.97, S 19.96.

1-Ethyl-5-thophen-3-yl-6-thophen-2-yl-1,6-dihydropyrazine-2,3-dicarbonitrile (11c). Yield of the racemate (see Table 1, entry 7), bright yellow powder, mp 113-114 ${ }^{\circ} \mathrm{C}$. Racemate was separated by chiral HPLC with a Kromasil 5-CelluCoat $(150 \times 4.6 \mathrm{~mm}, 5 \mu \mathrm{m})$ column. The 
eluent mixture $\mathrm{CH}_{3} \mathrm{CN}-\mathrm{H}_{2} \mathrm{O} 65: 35$ was used in isocratic mode $\left(0.8 \mathrm{~mL} / \mathrm{min}\right.$ at $\left.25{ }^{\circ} \mathrm{C}\right)$, and the UV signal was monitored at $\lambda 268 \mathrm{~nm}$ to obtain the resolved enantiomeric pair $\boldsymbol{R}$-(-)-11c/S-(-)11c $\left(t_{\mathrm{R}} 4.67, t_{\mathrm{R}}\right.$ 6.18). R-(-)-11c: $[\alpha]_{\mathrm{D}}{ }^{20}-1001$ (c $\left.0.25, \mathrm{CH}_{3} \mathrm{CN}\right)$, ee $>99.9 \%$ (Kromasil 5CelluCoat, $\mathrm{CH}_{3} \mathrm{CN}-\mathrm{H}_{2} \mathrm{O}$ 70:30, $\left.t_{\mathrm{R}} 4.67\right) ; \boldsymbol{S}-(+)-11 \mathrm{c}:[\alpha]_{\mathrm{D}}{ }^{20}+907$ (c $0.25, \mathrm{CH}_{3} \mathrm{CN}$ ), ee $94.2 \%$ (Kromasil 5-CelluCoat, $\left.\mathrm{CH}_{3} \mathrm{CN}-\mathrm{H}_{2} \mathrm{O} 70: 30, t_{\mathrm{R}} 6.33\right)$. $\delta_{\mathrm{H}}\left(500 \mathrm{MHz}, \mathrm{CDCl}_{3}\right) 1.34\left(\mathrm{t}, 3 \mathrm{H}, \mathrm{CH}_{3}, J\right.$ $7.2 \mathrm{~Hz}), 3.68\left(\mathrm{dq}, 1 \mathrm{H}, \mathrm{NCH}^{\mathrm{B}}, J 14.3,7.2 \mathrm{~Hz}\right), 3.73\left(\mathrm{dq}, 1 \mathrm{H}, \mathrm{NCH}^{\mathrm{A}}, J 14.3,7.2\right), 5.82(\mathrm{~s}, 1 \mathrm{H}, \mathrm{H} 6)$, 6.93 (dm, 1H, H3', J 3.6 Hz), 6.97 (dd, 1H, H4', J 5.0, 3.6 Hz), 7.32 (dd, 1H, H5', J 5.0, 1.2 Hz), 7.37 (dd, 1H, H4", J 5.1, 2.8 Hz), 7.64 (dd, 1H, H5", J 5.1, 1.2 Hz), 7.78 (dd, 1H, H2", J 2.8, 1.2 $\mathrm{Hz}) . \delta_{\mathrm{C}}\left(126 \mathrm{MHz}, \mathrm{CDCl}_{3}\right) 14.80\left(\mathrm{CH}_{3}\right), 48.18\left(\mathrm{CH}_{2}\right), 53.44(\mathrm{C} 6), 110.18(\mathrm{CN}), 111.34(\mathrm{CN})$, 116.05 (C3), 118.14 (C2), 127.09 (C5"), 127.21 (C4"), 127.29 (C3'), 127.32 (C5'), 127.47 (C4'), 128.76 (C2"), 136.98 (C2'), 137.89 (C3"), 143.87 (C5). GC t $29.28 \mathrm{~min} ; \mathrm{MS} \mathrm{m} / \mathrm{z}$ (rel intensity) $324\left(\mathrm{M}^{+}, 100\right)$. Calcd. for $\mathrm{C}_{16} \mathrm{H}_{12} \mathrm{~N}_{4} \mathrm{~S}_{2}$ (324.43): C 59.24, H 3.73, N 17.27, S 19.77. Found C 59.45, H 3.62, N 16.95, S 19.98.

1-Ethyl-5-phenyl-6-thiophen-3-yl-1,6-dihydropyrazine-2,3-dicarbonitrile (12a). Yield of the racemate (see Table 1, entry 4), dark yellow powder, mp $154-155^{\circ} \mathrm{C}$. Racemate was separated by chiral HPLC with a Kromasil 5-CelluCoat $(150 \times 4.6 \mathrm{~mm}, 5 \mu \mathrm{m})$ column. The eluent mixture $\mathrm{CH}_{3} \mathrm{CN}-\mathrm{H}_{2} \mathrm{O} 60: 40$ was used in isocratic mode $\left(0.6 \mathrm{~mL} / \mathrm{min}\right.$ at $\left.25^{\circ} \mathrm{C}\right)$, and the $\mathrm{UV}$ signal was monitored at $\lambda 268 \mathrm{~nm}$ to obtain the resolved enantiomeric pair $\boldsymbol{R}-(-)-12 a / S-(-)-12 a\left(t_{\mathrm{R}} 9.44, t_{\mathrm{R}}\right.$ 13.97). $\boldsymbol{R}$-(-)-12a: $[\alpha]_{\mathrm{D}}{ }^{20}-927$ (c $0.25, \mathrm{CH}_{3} \mathrm{CN}$ ), ee $99.7 \%$ (Kromasil 5-CelluCoat, $\mathrm{CH}_{3} \mathrm{CN}-\mathrm{H}_{2} \mathrm{O}$ 60:40, $\left.t_{\mathrm{R}} 6.05\right) ; \boldsymbol{S}-(+)-12 \mathrm{a}:[\alpha]_{\mathrm{D}}{ }^{20}+859\left(\mathrm{c} 0.25, \mathrm{CH}_{3} \mathrm{CN}\right)$, ee $97.6 \%$ (Kromasil 5-CelluCoat, $\left.\mathrm{CH}_{3} \mathrm{CN}-\mathrm{H}_{2} \mathrm{O} 60: 40, t_{\mathrm{R}} 9.00\right) . \delta_{\mathrm{H}}\left(500 \mathrm{MHz}, \mathrm{CDCl}_{3}\right) 1.31\left(\mathrm{t}, 3 \mathrm{H}, \mathrm{CH}_{3}, J 7.2 \mathrm{~Hz}\right), 3.68(\mathrm{dq}, 1 \mathrm{H}$, $\left.\mathrm{NCH}^{\mathrm{B}}, J 14.5,7.2 \mathrm{~Hz}\right), 3.76\left(\mathrm{dq}, 1 \mathrm{H}, \mathrm{NCH}^{\mathrm{A}}, J 14.5,7.2 \mathrm{~Hz}\right), 5.82$ (s, 1H, H6), 6.98 (dd, 1H, H5', $J$ 5.1, $1.4 \mathrm{~Hz}$ ), 7.14 (ddd, 1H, H2', J 2.9, 1.4, $0.8 \mathrm{~Hz}$ ), 7.36 (dd, 1H, H4', J 5.1, 2.9), 7.44 (m, 2H, $\mathrm{Hm}), 7.49(\mathrm{~m}, 1 \mathrm{H}, \mathrm{Hp}), 7.89(\mathrm{~m}, 2 \mathrm{H}, \mathrm{Ho}) . \delta_{\mathrm{C}}\left(126 \mathrm{MHz}, \mathrm{CDCl}_{3}\right) 15.11\left(\mathrm{CH}_{3}\right), 48.60\left(\mathrm{NCH}_{2}\right)$, 52.83 (C6), $110.21(\mathrm{CN}), 111.41(\mathrm{CN}), 116.12$ (C3), $118.37(\mathrm{C} 2), 124.71\left(\mathrm{C} 2{ }^{\prime}\right), 125.70$ (C5'), 127.92 (Co), 128.06 (C4'), $129.01(\mathrm{Cm}), 131.85$ (Cp), 133.95 (Ci), 135.44 (C3'), 147.78 (C5). $\mathrm{GC} \mathrm{t}_{R} 29.10 \mathrm{~min} ; \mathrm{MS} \mathrm{m} / \mathrm{z}$ (rel intensity) $318\left(\mathrm{M}^{+}, 100\right)$. Calcd. for $\mathrm{C}_{18} \mathrm{H}_{14} \mathrm{~N}_{4} \mathrm{~S}$ (318.40): C 67.90, H 4.43, N 17.60. Found C 68.05, H 4.65, N 17.55.

1-Ethyl-5-thiophen-2-yl-6-thiophen-3-yl-1,6-dihydropyrazine-2,3-dicarbonitrile (12b). Yield of the racemate (see Table 1, entry 6), bright yellow powder, mp 141-143 ${ }^{\circ} \mathrm{C}$. Racemate was separated by chiral HPLC with a Kromasil 5-CelluCoat $(150 \times 4.6 \mathrm{~mm}, 5 \mu \mathrm{m})$ column. The eluent mixture $\mathrm{CH}_{3} \mathrm{CN}-\mathrm{H}_{2} \mathrm{O} 65: 35$ was used in isocratic mode $\left(20 \mathrm{~mL} / \mathrm{min}\right.$ at $\left.25^{\circ} \mathrm{C}\right)$, and the UV signal was monitored at $\lambda 280 \mathrm{~nm}$ to obtain the resolved enantiomeric pair $\boldsymbol{R}-(-)-\mathbf{1 2 b} / \boldsymbol{S}-(-)-\mathbf{1 2 b}$ $\left(t_{\mathrm{R}} 3.42, t_{\mathrm{R}} 4.36\right)$. $\boldsymbol{R}-(-)-12 \mathrm{~b}:[\alpha]_{\mathrm{D}}{ }^{20}-1475$ (c $0.25, \mathrm{CH}_{3} \mathrm{CN}$ ), ee $>99.9 \%$ (Kromasil 5-CelluCoat, $\mathrm{CH}_{3} \mathrm{CN}-\mathrm{H}_{2} \mathrm{O}$ 60:40, $t_{\mathrm{R}}$ 5.68); $\boldsymbol{S}$-(+)-12b: $[\alpha]_{\mathrm{D}}{ }^{20}+907\left(\mathrm{c} 0.25, \mathrm{CH}_{3} \mathrm{CN}\right.$ ), ee $93.5 \%$ (Kromasil 5CelluCoat, $\left.\mathrm{CH}_{3} \mathrm{CN}-\mathrm{H}_{2} \mathrm{O} 60: 40, t_{\mathrm{R}} 7.32\right)$. $\delta_{\mathrm{H}}\left(500 \mathrm{MHz}, \mathrm{CDCl}_{3}\right) 1.31\left(\mathrm{t}, 3 \mathrm{H}, \mathrm{CH}_{3}, J 7.2 \mathrm{~Hz}\right), 3.65$ $\left(\mathrm{dq}, 1 \mathrm{H}, \mathrm{NCH}^{\mathrm{B}}, J 14.5,7.2 \mathrm{~Hz}\right), 3.73\left(\mathrm{dq}, 1 \mathrm{H}, \mathrm{NCH}^{\mathrm{A}}, J 14.5,7.2 \mathrm{~Hz}\right), 5.72(\mathrm{~s}, 1 \mathrm{H}, \mathrm{H} 6), 6.98$ (dd, 1H, H5', J 5.1, 1.4 Hz), 7.09 (dd, 1H, H4", J 5.1, 3.8 Hz), 7.18 (ddd, 1H, H2', J 2.9, 1.4, 0.7 Hz), 7.36 (dd, 1H, H4', J 5.1, 2.9 Hz), 7.45 (dd, 1H, H3", J 3.8, 1.1 Hz), 7.56 (dd, 1H, H5", J 5.1, 1.1 Hz). $\delta_{\mathrm{C}}\left(126 \mathrm{MHz}, \mathrm{CDCl}_{3}\right): 14.82\left(\mathrm{CH}_{3}\right), 48.49\left(\mathrm{CH}_{2}\right), 53.88(\mathrm{C} 6), 109.89(\mathrm{CN}), 111.43(\mathrm{CN})$, 
115.96 (C3), 118.37 (C2), 124.32 (C2'), 125.65 (C5'), 128.09 (C4'), 128.21 (C4"), 129.69 (C3"), 132.85 (C5"), 135.70 (C3'), 140.75 (C2"), 143.50 (C5). GC t $29.63 \mathrm{~min} ; \mathrm{MS} \mathrm{m} / \mathrm{z}$ (rel intensity) $324\left(\mathrm{M}^{+}, 100\right)$. Calcd. For $\mathrm{C}_{16} \mathrm{H}_{12} \mathrm{~N}_{4} \mathrm{~S}_{2}$ (324.43): C 59.24, H 3.73, N 17.27, S 19.77. Found C 59.36, H 3.54, N 17.18, S 19.92.

1-Ethyl-5,6-dithiophen-3-yl-1,6-dihydropyrazine-2,3-dicarbonitrile (12c). Yield of the racemate (see Table 1, entry 8), bright yellow powder, mp 113-114 ${ }^{\circ} \mathrm{C}$. Racemate was separated by chiral HPLC with a Kromasil 5-CelluCoat $(150 \times 4.6 \mathrm{~mm}, 5 \mu \mathrm{m})$ column. The eluent mixture $\mathrm{CH}_{3} \mathrm{CN}-\mathrm{H}_{2} \mathrm{O} 65: 35$ was used in isocratic mode $\left(0.8 \mathrm{~mL} / \mathrm{min}\right.$ at $\left.25^{\circ} \mathrm{C}\right)$, and the $\mathrm{UV}$ signal was monitored at $\lambda 270 \mathrm{~nm}$ to obtain the resolved enantiomeric pair $\boldsymbol{R}-(-)-\mathbf{1 2 c} / \boldsymbol{S}-(-)-\mathbf{1 2 c}\left(t_{\mathrm{R}} 5.08, t_{\mathrm{R}}\right.$ 6.60). $\boldsymbol{R}$-(-)-12c: $[\alpha]_{\mathrm{D}}{ }^{20}-992$ (c $0.25, \mathrm{CH}_{3} \mathrm{CN}$ ), ee $>99.9 \%$ (Kromasil 5-CelluCoat, $\mathrm{CH}_{3} \mathrm{CN}-\mathrm{H}_{2} \mathrm{O}$ 65:35, $\left.t_{\mathrm{R}} 4.61\right) ; \boldsymbol{S}-(+)-12 \mathrm{c}:[\alpha]_{\mathrm{D}}{ }^{20}+967\left(\mathrm{c} 0.25, \mathrm{CH}_{3} \mathrm{CN}\right)$, ee $95.2 \%$ (Kromasil 5-CelluCoat, $\left.\mathrm{CH}_{3} \mathrm{CN}-\mathrm{H}_{2} \mathrm{O} 65: 35, t_{\mathrm{R}} 6.23\right) . \delta_{\mathrm{H}}\left(500 \mathrm{MHz}, \mathrm{CDCl}_{3}\right) 1.31\left(\mathrm{t}, 3 \mathrm{H}, \mathrm{CH}_{3}, J 7.3 \mathrm{~Hz}\right), 3.65(\mathrm{dq}, 1 \mathrm{H}$, $\mathrm{NCH}^{\mathrm{B}}, J$ 14.5, 7.3 Hz), $3.73\left(\mathrm{dq}, 1 \mathrm{H}, \mathrm{NCH}^{\mathrm{A}}, J\right.$ 14.5, $\left.7.3 \mathrm{~Hz}\right), 5.67$ (s, 1H, H6), 6.97 (dd, 1H, H5', $J$ 5.1, $1.4 \mathrm{~Hz}$ ), 7.16 (ddd, 1H, H2', J 2.9, 1.4, $0.7 \mathrm{~Hz}$ ), 7.36 (dd, 1H, H4', J 5.1, 2.9 Hz), 7.37 (dd, $1 \mathrm{H}, \mathrm{H} 4 ", J 5.1,2.9 \mathrm{~Hz}), 7.64$ (dd, 1H, H5", J 5.1, $1.3 \mathrm{~Hz}), 7.75$ (dd, 1H, H2", J 2.9, $1.3 \mathrm{~Hz}$ ). $\delta_{\mathrm{C}}$ $\left(126 \mathrm{MHz}, \mathrm{CDCl}_{3}\right) 14.90\left(\mathrm{CH}_{3}\right), 48.42\left(\mathrm{CH}_{2}\right), 53.95(\mathrm{C} 6), 109.90(\mathrm{CN}), 111.44(\mathrm{CN}), 116.17$ (C3), 118.28 (C2), 124.38 (C2'), 125.68 (C5'), 127.12 (C5"), 127.19 (C4"), 128.13 (C4'), 128.52 (C2"), 135.74 (C3'), 138.21 (C3"), 144.19 (C5). GC t $29.59 \mathrm{~min}$; MS m/z (rel intensity) 324 $\left(\mathrm{M}^{+}, 100\right)$. Calcd. for $\mathrm{C}_{16} \mathrm{H}_{12} \mathrm{~N}_{4} \mathrm{~S}_{2}$ (324.43): C 59.24, H 3.73, N 17.27, S 19.77. Found C 58.98, H $3.40, \mathrm{~N} 17.39$, S 20.23 .

\section{6-Benzo $[b]$ thiophen-2-yl-1-ethyl-5-phenyl-1,6-dihydropyrazine-2,3-dicarbonitrile}

(15a). Yield of the racemate (see Table 1, entry 9), bright yellow powder, mp $68-70{ }^{\circ} \mathrm{C}$. Racemate was separated by chiral HPLC with a Kromasil 5-CelluCoat $(150 \times 4.6 \mathrm{~mm}, 5 \mu \mathrm{m})$ column. The eluent mixture $\mathrm{CH}_{3} \mathrm{CN}-\mathrm{H}_{2} \mathrm{O} 75: 25$ was used in isocratic mode $\left(0.6 \mathrm{~mL} / \mathrm{min}\right.$ at $\left.25{ }^{\circ} \mathrm{C}\right)$, and the UV signal was monitored at $\lambda 265 \mathrm{~nm}$ to obtain the resolved enantiomeric pair $\boldsymbol{R}$-(-)-15a/S-(-)15a $\left(t_{\mathrm{R}}\right.$ 6.94, $t_{\mathrm{R}}$ 10.51). $\boldsymbol{R}$-(-)-15a: $[\alpha]_{\mathrm{D}}{ }^{20}-955\left(\mathrm{c} 0.25, \mathrm{CH}_{3} \mathrm{CN}\right)$, ee $>99.9 \%$ (Kromasil 5CelluCoat, $\mathrm{CH}_{3} \mathrm{CN}-\mathrm{H}_{2} \mathrm{O}$ 70:30, $t_{\mathrm{R}}$ 4.67); $\boldsymbol{S}$-(+)-15a: $[\alpha]_{\mathrm{D}}{ }^{20}+918$ (c $0.25, \mathrm{CH}_{3} \mathrm{CN}$ ), ee $94.2 \%$ (Kromasil 5-CelluCoat, $\left.\mathrm{CH}_{3} \mathrm{CN}-\mathrm{H}_{2} \mathrm{O} 70: 30, t_{\mathrm{R}} 6.33\right)$. $\delta_{\mathrm{H}}\left(500 \mathrm{MHz}, \mathrm{CDCl}_{3}\right) 1.38\left(\mathrm{t}, 3 \mathrm{H}, \mathrm{CH}_{3}, J\right.$ $7.2 \mathrm{~Hz}), 3.75\left(\mathrm{dq}, 1 \mathrm{H}, \mathrm{NCH}^{\mathrm{B}}, J 14.5,7.2 \mathrm{~Hz}\right), 3.82\left(\mathrm{dq}, 1 \mathrm{H}, \mathrm{NCH}^{\mathrm{A}}, J 14.5,7.2 \mathrm{~Hz}\right), 6.02(\mathrm{~d}, 1 \mathrm{H}$, H6, J 0.8 Hz), 7.11 (s, 1H, H3'), 7.34-7.38 (m, 2H, H5',6'), 7.46 (m, 2H, Hm), 7.51 (t, 1H, Hp, J 7.2, $1.4 \mathrm{~Hz}), 7.70(\mathrm{~m}, 1 \mathrm{H}, \mathrm{H} 4$ '), 7.79 (m, 1H, H7'), 7.95 (dd, 2H, Ho, J 8.4, $1.3 \mathrm{~Hz}) . \delta_{\mathrm{C}}(126$ $\left.\mathrm{MHz}, \mathrm{CDCl}_{3}\right) 15.10\left(\mathrm{CH}_{3}\right), 48.72\left(\mathrm{NCH}_{2}\right), 53.18(\mathrm{C} 6), 110.88(\mathrm{CN}), 111.24(\mathrm{CN}), 115.87(\mathrm{C} 3)$, 118.21 (C2), 122.41 (C7'), 124.20 (C4'), 124.56 (C3'), 125.04 and 125.62 (C5' and C6'), 128.04 (Co), 129.10 (Cm), 132.09 (Cp), 133.66 (Ci), 136.94 (C2'), 138.68 (C3'a), 139.79 (C7'a), 146.99 (C5). GC t $36.22 \mathrm{~min} ; \mathrm{MS} \mathrm{m} / \mathrm{z}$ (rel intensity) $368\left(\mathrm{M}^{+}, 100\right)$. Calcd. for $\mathrm{C}_{22} \mathrm{H}_{16} \mathrm{~N}_{4} \mathrm{~S}$ (368.46): C 71.72, H 4.38, N 15.21. Found C 71.68, H 4.44, N 15.48.

\section{6-Benzo $[b]$ thiophen-2-yl-1-ethyl-5-thiophen-2-yl-1,6-dihydropyrazine-2,3-dicarbonitrile} (15b). Yield of the racemate (see Table 1, entry 10), dark yellow powder, mp 77-79 ${ }^{\circ} \mathrm{C}$. Racemate was separated by chiral HPLC with a Kromasil 5-CelluCoat $(150 \times 4.6 \mathrm{~mm}, 5 \mu \mathrm{m})$ column. The eluent mixture $\mathrm{CH}_{3} \mathrm{CN}-\mathrm{H}_{2} \mathrm{O}$ 80:20 was used in isocratic mode $(20 \mathrm{~mL} / \mathrm{min}$ at 25 
$\left.{ }^{\circ} \mathrm{C}\right)$, and the UV signal was monitored at $\lambda 280 \mathrm{~nm}$ to obtain the resolved enantiomeric pair $\boldsymbol{R}-(-)-$ $\mathbf{1 5 b} / \boldsymbol{S}-(-)-15 \mathbf{b}\left(t_{\mathrm{R}} 3.41, t_{\mathrm{R}} 4.21\right)$. $\boldsymbol{R}-(-)-15 \mathbf{b}:[\alpha]_{\mathrm{D}}{ }^{20}-1615\left(\mathrm{c} 0.25, \mathrm{CH}_{3} \mathrm{CN}\right)$, ee $>99.9 \%$ (Kromasil 5-CelluCoat, $\left.\mathrm{CH}_{3} \mathrm{CN}-\mathrm{H}_{2} \mathrm{O} 70: 30, t_{\mathrm{R}} 4.67\right)$; $\boldsymbol{S}$-(+)-15b: $[\alpha]_{\mathrm{D}}{ }^{20}+1578\left(\mathrm{c} 0.25, \mathrm{CH}_{3} \mathrm{CN}\right.$ ), ee $94.2 \%$ (Kromasil 5-CelluCoat, $\left.\mathrm{CH}_{3} \mathrm{CN}-\mathrm{H}_{2} \mathrm{O} 70: 30, t_{\mathrm{R}} 6.33\right) . \delta_{\mathrm{H}}\left(500 \mathrm{MHz}, \mathrm{CDCl}_{3}\right) 1.37\left(\mathrm{t}, 3 \mathrm{H}, \mathrm{CH}_{3}, J\right.$ $7.2 \mathrm{~Hz}), 3.72\left(\mathrm{dq}, 1 \mathrm{H}, \mathrm{NCH}^{\mathrm{B}}, J 14.5,7.2 \mathrm{~Hz}\right), 3.78\left(\mathrm{dq}, 1 \mathrm{H}, \mathrm{NCH}^{\mathrm{A}}, J 14.5,7.2 \mathrm{~Hz}\right), 5.92(\mathrm{~s}, 1 \mathrm{H}$, H6), 7.11 (dd, 1H, H4", J 5.0, 3.9 Hz), 7.15 (s, 1H, H3'), 7.34-7.39 (m, 2H, H5',6'), 7.52 (dd, 1H, H3", J 3.9, $1.0 \mathrm{~Hz}), 7.59$ (dd, 1H, H5", $J$ 5.0, $\left.1.0 \mathrm{~Hz}), 7.72\left(\mathrm{~m}, 1 \mathrm{H}, \mathrm{H} 4{ }^{\prime}\right), 7.78(\mathrm{~m}, 1 \mathrm{H}, \mathrm{H} 7)^{\prime}\right) . \delta_{\mathrm{C}}$ $\left(126 \mathrm{MHz}, \mathrm{CDCl}_{3}\right) 14.84\left(\mathrm{CH}_{3}\right), 48.63\left(\mathrm{NCH}_{2}\right), 110.68(\mathrm{CN}), 111.28(\mathrm{CN}), 115.67(\mathrm{C} 3), 118.17$ (C2), 122.43 (C7'), 124.09 (C3'), 124.19 (C4'), 125.07 (C6'), 125.63 (C5'), 128.30 (C4'), 129.95 (C3"), 133.24 (C5"), 137.17 (C2'), 138.66 (C3'a), 139.74 (C7'a), 140.44 (C2"), 142.74 (C5). GC $\mathrm{t}_{R} 37.35 \mathrm{~min} ; \mathrm{MS} \mathrm{m} / \mathrm{z}$ (rel intensity) $374\left(\mathrm{M}^{+}, 100\right)$. Calcd. for $\mathrm{C}_{20} \mathrm{H}_{14} \mathrm{~N}_{4} \mathrm{~S}_{2}$ (374.49): $\mathrm{C} 64.15, \mathrm{H}$ 3.77, N 14.96. Found C 63.91, H 3.56, N 15.02.

\section{6-Benzo $[b]$ thiophen-2-yl-1-ethyl-5-thiophen-3-yl-1,6-dihydropyrazine-2,3-dicarbonitrile}

(15c). Yield of the racemate (see Table 1, entry 11), dark yellow powder, mp 75-77 ${ }^{\circ} \mathrm{C}$. Racemate was separated by chiral HPLC with a Kromasil 5-CelluCoat $(150 \times 4.6 \mathrm{~mm}, 5 \mu \mathrm{m})$ column. The eluent mixture $\mathrm{CH}_{3} \mathrm{CN}-\mathrm{H}_{2} \mathrm{O}$ 65:35 was used in isocratic mode $(0.8 \mathrm{~mL} / \mathrm{min}$ at 25 ${ }^{\circ} \mathrm{C}$ ), and the UV signal was monitored at $\lambda 265 \mathrm{~nm}$ to obtain the resolved enantiomeric pair $\boldsymbol{R}-(-)-$ $\mathbf{1 5 c} / \boldsymbol{S}-\mathbf{- ( - ) - 1 5 c}\left(t_{\mathrm{R}} 10.36, t_{\mathrm{R}}\right.$ 13.55). $\boldsymbol{R}-(-)-15 \mathbf{c}:[\alpha]_{\mathrm{D}}{ }^{20}-1026 \quad\left(\mathrm{c} 0.25, \mathrm{CH}_{3} \mathrm{CN}\right)$, ee $>99.9 \%$ (Kromasil 5-CelluCoat, $\left.\mathrm{CH}_{3} \mathrm{CN}-\mathrm{H}_{2} \mathrm{O} 70: 30, t_{\mathrm{R}} 4.67\right) ; \boldsymbol{S}-(+)-15 \mathrm{c}:[\alpha]_{\mathrm{D}}{ }^{20}+830$ (c $0.25, \mathrm{CH}_{3} \mathrm{CN}$ ), ee $94.2 \%$ (Kromasil 5-CelluCoat, $\left.\mathrm{CH}_{3} \mathrm{CN}-\mathrm{H}_{2} \mathrm{O} 70: 30, t_{\mathrm{R}} 6.33\right) . \delta_{\mathrm{H}}\left(500 \mathrm{MHz}, \mathrm{CDCl}_{3}\right) 1.37(\mathrm{t}$, $\left.3 \mathrm{H}, \mathrm{CH}_{3}, J 7.2 \mathrm{~Hz}\right), 3.72\left(\mathrm{dq}, 1 \mathrm{H}, \mathrm{NCH}^{\mathrm{B}}, J 14.5,7.2 \mathrm{~Hz}\right), 3.79\left(\mathrm{dq}, 1 \mathrm{H}, \mathrm{NCH}^{\mathrm{A}}, J 14.5,7.2 \mathrm{~Hz}\right)$, 5.87 (s, 1H, H6), 7.13 (s, 1H, H3'), 7.35-7.39 (m, 2H, H5',6'), 7.39 (dd, 1H, H5", J 5.1, 2.8 Hz), 7.68 (dd, 1H, H4", J 5.1, 1.4 Hz), 7.72 (m, 1H, H4'), 7.78 (m, 1H, H7'), 7.84 (dd, 1H, H2", J 2.8, $1.4 \mathrm{~Hz}) . \delta_{\mathrm{C}}\left(126 \mathrm{MHz}, \mathrm{CDCl}_{3}\right) 14.92\left(\mathrm{CH}_{3}\right), 48.56\left(\mathrm{NCH}_{2}\right), 54.27(\mathrm{C} 6), 110.60(\mathrm{CN}), 111.28$ $(\mathrm{CN}), 115.92(\mathrm{C} 3), 118.10(\mathrm{C} 2), 122.43$ (C7'), 124.17 and 124.19 (C3' and C4'), 125.08 and 125.62 (C5' and C6'), 127.12 (C4"), 127.39 (C5"), 128.91 (C2"), 137.20 (C2'), 137.91 (C3"), 138.70 (C3'a), 139.75 (C7'a), 143.40 (C5). GC t $37.36 \mathrm{~min} ; \mathrm{MS} \mathrm{m} / \mathrm{z}$ (rel intensity) $374\left(\mathrm{M}^{+}\right.$, 100). Calcd. for $\mathrm{C}_{20} \mathrm{H}_{14} \mathrm{~N}_{4} \mathrm{~S}_{2}$ (374.49): $\mathrm{C}$ 64.15, H 3.77, $\mathrm{N}$ 14.96. Found $\mathrm{C}$ 64.08, H 3.77, $\mathrm{N}$ 14.70.

\section{6-Benzo[b]thiophen-3-yl-1-ethyl-5-phenyl-1,6-dihydropyrazine-2,3-dicarbonitrile}

(16a). Yield of the racemate (see Table 1, entry 12), yellow powder, mp 174-176 ${ }^{\circ} \mathrm{C}$. Racemate was separated by chiral HPLC with a Kromasil 5-CelluCoat $(150 \times 4.6 \mathrm{~mm}, 5 \mu \mathrm{m})$ column. The eluent mixture $\mathrm{CH}_{3} \mathrm{CN}-\mathrm{H}_{2} \mathrm{O} 75: 25$ was used in isocratic mode $\left(0.6 \mathrm{~mL} / \mathrm{min}\right.$ at $\left.25^{\circ} \mathrm{C}\right)$, and the UV signal was monitored at $\lambda 265 \mathrm{~nm}$ to obtain the resolved enantiomeric pair $\boldsymbol{R}$-(-)-16a/S-(-)16a $\left(t_{\mathrm{R}}\right.$ 6.18, $t_{\mathrm{R}}$ 8.79). $\boldsymbol{R}-(-)-16 a:[\alpha]_{\mathrm{D}}{ }^{20}-751$ (c $0.25, \mathrm{CH}_{3} \mathrm{CN}$ ), ee $>99.9 \%$ (Kromasil 5CelluCoat, $\mathrm{CH}_{3} \mathrm{CN}-\mathrm{H}_{2} \mathrm{O}$ 70:30, $t_{\mathrm{R}}$ 4.67); $\boldsymbol{S}$-(+)-16a: $[\alpha]_{\mathrm{D}}{ }^{20}+776$ (c $\left.0.25, \mathrm{CH}_{3} \mathrm{CN}\right)$, ee $94.2 \%$ (Kromasil 5-CelluCoat, $\left.\mathrm{CH}_{3} \mathrm{CN}-\mathrm{H}_{2} \mathrm{O} 70: 30, t_{\mathrm{R}} 6.33\right)$. $\delta_{\mathrm{H}}\left(500 \mathrm{MHz}, \mathrm{CDCl}_{3}\right) 1.28\left(\mathrm{t}, 3 \mathrm{H}, \mathrm{CH}_{3}, J\right.$ $7.2 \mathrm{~Hz}), 3.70\left(\mathrm{dq}, 1 \mathrm{H}, \mathrm{NCH}^{\mathrm{B}}, J 14.4,7.2 \mathrm{~Hz}\right), 3.83\left(\mathrm{dq}, 1 \mathrm{H}, \mathrm{NCH}^{\mathrm{A}}, J 14.4,7.2 \mathrm{~Hz}\right), 6.08(\mathrm{~s}, 1 \mathrm{H}$, H6), 7.27 (s, 1H, H2'), 7.38 (dd, 1H, Hm, J 8.3, 7.2 Hz), 7.45 (tt, 1H, Hp, J 7.2, 1.2 Hz), 7.48 (ddd, 1H, H6', $J$ 8.2, 7.1, $1.0 \mathrm{~Hz}$ ), 7.56 (ddd, 1H, H5', J 8.1, 7.2, $1.0 \mathrm{~Hz}), 7.81\left(\mathrm{~m}, 2 \mathrm{H}, \mathrm{Ho}\right.$ ),. $\delta_{\mathrm{C}}$ 
$\left(126 \mathrm{MHz}, \mathrm{CDCl}_{3}\right) 15.05\left(\mathrm{CH}_{3}\right), 49.14\left(\mathrm{NCH}_{2}\right), 51.02(\mathrm{C} 6), 110.70(\mathrm{CN}), 111.35(\mathrm{CN}), 116.14$ (C3), 118.06 (C2), 120.39 (C4'), 123.66 (C7'), 125.20 (C6'), 125.28 (C5'), 127.80 (Co), 128.99 (Cm), 129,16 (С2э)б 129.20 (C3'), 131.95 (Cp), 133.72 (Ci), 136.25 (C3'a), 140.99 (C7'a), 148.03 (C5). GC t $35.29 \mathrm{~min} ; \mathrm{MS} \mathrm{m} / \mathrm{z}$ (rel intensity) $368\left(\mathrm{M}^{+}, 100\right)$. Calcd. for $\mathrm{C}_{22} \mathrm{H}_{16} \mathrm{~N}_{4} \mathrm{~S}$ (368.46): C 71.72, H 4.38, N 15.21. Found C 71.63, H 4.29, N 15.39.

6-Benzo $[b]$ thiophen-3-yl-1-ethyl-5-thiophen-2-yl-1,6-dihydropyrazine-2,3-dicarbonitrile (16b). Yield of the racemate (see Table 1, entry 13), yellow powder, mp 224-226 ${ }^{\circ} \mathrm{C}$ (decomp.). Racemate was separated by chiral HPLC with a Kromasil 5-CelluCoat $(150 \times 4.6 \mathrm{~mm}, 5 \mu \mathrm{m})$ column. The eluent mixture $\mathrm{CH}_{3} \mathrm{CN}-\mathrm{H}_{2} \mathrm{O} 80: 20$ was used in isocratic mode $(20 \mathrm{~mL} / \mathrm{min}$ at 25 ${ }^{\circ} \mathrm{C}$ ), and the UV signal was monitored at $\lambda 227 \mathrm{~nm}$ to obtain the resolved enantiomeric pair $\boldsymbol{R}-(-)-$ 16b/S-(-)-16b $\left(t_{\mathrm{R}} 3.12, t_{\mathrm{R}} 4.18\right)$. $\boldsymbol{R}-(-)-16 \mathbf{b}:[\alpha]_{\mathrm{D}}{ }^{20}-1035$ (c $0.25, \mathrm{CH}_{3} \mathrm{CN}$ ), ee $>99.9 \%$ (Kromasil 5-CelluCoat, $\mathrm{CH}_{3} \mathrm{CN}-\mathrm{H}_{2} \mathrm{O}$ 75:25, $t_{\mathrm{R}}$ 6.32); $\boldsymbol{S}$-(+)-16b: $[\alpha]_{\mathrm{D}}{ }^{20}+941$ (c $0.25, \mathrm{CH}_{3} \mathrm{CN}$ ), ee $98.1 \%$ (Kromasil 5-CelluCoat, $\left.\mathrm{CH}_{3} \mathrm{CN}-\mathrm{H}_{2} \mathrm{O} 75: 25, t_{\mathrm{R}} 7.58\right) . \delta_{\mathrm{H}}\left(500 \mathrm{MHz}, \mathrm{CDCl}_{3}\right) 1.28\left(\mathrm{t}, 3 \mathrm{H}, \mathrm{CH}_{3}, J\right.$ $7.2 \mathrm{~Hz}), 3.65\left(\mathrm{dq}, 1 \mathrm{H}, \mathrm{NCH}^{\mathrm{B}}, J 14.4,7.2 \mathrm{~Hz}\right), 3.77\left(\mathrm{dq}, 1 \mathrm{H}, \mathrm{NCH}^{\mathrm{A}}, J 14.4,7.2 \mathrm{~Hz}\right), 6.00(\mathrm{~s}, 1 \mathrm{H}$, H6), 6.99 (dd, 1H, H4", J 5.0, 3.9 Hz), 7.29 (dd, 1H, H3", J 3.9, 1.0 Hz), 7.35 (s, 1H, H2'), 7.47 (ddd, 1H, H6', J 8.2, 7.1, 1.0 Hz), 7.56 (ddd, 1H, H5', J 8.1, 7.1, $1.0 \mathrm{~Hz}$ ), 7.91-7.94 (m, 2H, $\left.\mathrm{H}^{\prime}, 7^{\prime}\right) . \delta_{\mathrm{C}}\left(126 \mathrm{MHz}, \mathrm{CDCl}_{3}\right) 14.64\left(\mathrm{CH}_{3}\right), 48.85\left(\mathrm{NCH}_{2}\right), 51.73(\mathrm{C} 6), 110.05(\mathrm{CN}), 111.37$ (CN), 115.99 (C3), 118.19 (C2), 120.24 (C4'), 123.65 (C7'), 125.22 (C6'), 125.36 (C5'), 128.19 (C4"), 128.67 (C2'), 129.48 (C3"), 130.07 (C2'), 132.81 (C5"), 136.41 (C3'a), 140.48 (C2"), 140.79 (C7'a), 143.98 (C5). GC t $36.61 \mathrm{~min}$; MS m/z (rel intensity) 374 ( $\left.\mathrm{M}^{+}, 100\right)$ ). Calcd. for $\mathrm{C}_{20} \mathrm{H}_{14} \mathrm{~N}_{4} \mathrm{~S}_{2}$ (374.49): C 64.15, H 3.77, N 14.96. Found C 63.91, H 3.56, N 15.02.

\section{6-Benzo $[b]$ thiophen-3-yl-1-ethyl-5-thiophen-3-yl-1,6-dihydropyrazine-2,3-dicarbonitrile}

(16c). Yield of the racemate (see Table 1, entry 14), yellow powder, mp $227-228{ }^{\circ} \mathrm{C}$. Racemate was separated by chiral HPLC with a Kromasil 5-CelluCoat $(150 \times 4.6 \mathrm{~mm}, 5 \mu \mathrm{m})$ column. The eluent mixture $\mathrm{CH}_{3} \mathrm{CN}-\mathrm{H}_{2} \mathrm{O} 80: 20$ was used in isocratic mode $\left(20 \mathrm{~mL} / \mathrm{min}\right.$ at $\left.25^{\circ} \mathrm{C}\right)$, and the UV signal was monitored at $\lambda 266 \mathrm{~nm}$ to obtain the resolved enantiomeric pair $\boldsymbol{R}-(-)-\mathbf{1 6} / \boldsymbol{S}-(-)-16 c\left(t_{\mathrm{R}}\right.$ 3.34, $t_{\mathrm{R}}$ 5.20). $\boldsymbol{R}$-(-)-16c: $[\alpha]_{\mathrm{D}}{ }^{20}-684\left(\mathrm{c} 0.25, \mathrm{CH}_{3} \mathrm{CN}\right.$ ), ee 99.3\% (Kromasil 5-CelluCoat, $\mathrm{CH}_{3} \mathrm{CN}-\mathrm{H}_{2} \mathrm{O}$ 75:25, $t_{\mathrm{R}}$ 5.68); $\boldsymbol{S}$-(+)-16c: $[\alpha]_{\mathrm{D}}{ }^{20}+679$ (c $0.25, \mathrm{CH}_{3} \mathrm{CN}$ ), ee $98.4 \%$ (Kromasil 5CelluCoat, $\left.\mathrm{CH}_{3} \mathrm{CN}-\mathrm{H}_{2} \mathrm{O} 75: 25, t_{\mathrm{R}} 9.31\right) . \delta_{\mathrm{H}}\left(500 \mathrm{MHz}, \mathrm{CDCl}_{3}\right) 1.28\left(\mathrm{t}, 3 \mathrm{H}, \mathrm{CH}_{3}, J 7.2 \mathrm{~Hz}\right), 3.65$ $\left(\mathrm{dq}, 1 \mathrm{H}, \mathrm{NCH}^{\mathrm{B}}, J 14.4,7.2 \mathrm{~Hz}\right), 3.77\left(\mathrm{dq}, 1 \mathrm{H}, \mathrm{NCH}^{\mathrm{A}}, J\right.$ 14.4, $\left.7.2 \mathrm{~Hz}\right), 5.94$ (s, 1H, H6), 7.32 (s, 1H, H2'), 7.33 (dd, 1H, H5", J 5.0, 2.9 Hz), 7.47 (ddd, 1H, H6', J 8.2, 7.1, 1.0 Hz), 7.56 (ddd, 1H, H5', J 8.1, 7.1, $1.0 \mathrm{~Hz}$ ), 7.60-7.62 (m, 2H, H4",2"), 7.91-7.95 (m, 2H, H4',7'). $\delta_{\mathrm{C}}(126 \mathrm{MHz}$, $\left.\mathrm{CDCl}_{3}\right) 14.75\left(\mathrm{CH}_{3}\right), 48.82\left(\mathrm{NCH}_{2}\right), 51.80(\mathrm{C} 6), 110.05(\mathrm{CN}), 111.37(\mathrm{CN}), 116.22(\mathrm{C} 3), 118.14$ (C2), 120.16 (C4'), 123.70 (C7'), 125.23 (C6'), 125.38 (C5'), 126.95 (C4"), 127.14 (C5"), 128.44 (C2"), 128.86 (C2'), 130.02 (C3'), 136.43 (C3'a), 137.97 (C3"), 140.88 (C7'a), 144.63 (C5). GC $\mathrm{t}_{R} 36.40 \mathrm{~min} ; \mathrm{MS} \mathrm{m} / \mathrm{z}$ (rel intensity) $374\left(\mathrm{M}^{+}, 100\right)$. Calcd. for $\mathrm{C}_{20} \mathrm{H}_{14} \mathrm{~N}_{4} \mathrm{~S}_{2}$ (374.49): $\mathrm{C} \mathrm{64.15,} \mathrm{H}$ 3.77, N 14.96. Found C 64.12, H 3.83, N 14.96.

1-Ethyl-6-furan-2-yl-5-phenyl-1,6-dihydropyrazine-2,3-dicarbonitrile (18a). Yield of the racemate (see Table 1, entry 15), yellow-orange powder, mp 137-140 ${ }^{\circ} \mathrm{C}$. Racemate was separated by chiral HPLC with a Kromasil 5-CelluCoat $(150 \times 4.6 \mathrm{~mm}, 5 \mu \mathrm{m})$ column. The 
eluent mixture $\mathrm{CH}_{3} \mathrm{CN}-\mathrm{H}_{2} \mathrm{O} 65: 35$ was used in isocratic mode $\left(0.6 \mathrm{~mL} / \mathrm{min}\right.$ at $\left.25{ }^{\circ} \mathrm{C}\right)$, and the UV signal was monitored at $\lambda 270 \mathrm{~nm}$ to obtain the resolved enantiomeric pair $\boldsymbol{R}-(-)-\mathbf{1 8 a} / \boldsymbol{S}-(-)-$ 18a $\left(t_{\mathrm{R}} 6.32, t_{\mathrm{R}}\right.$ 9.35). $\boldsymbol{R}$-(-)-18a: $[\alpha]_{\mathrm{D}}{ }^{20}-1032\left(\mathrm{c} 0.25, \mathrm{CH}_{3} \mathrm{CN}\right)$, ee $96.7 \%$ (Kromasil 5-CelluCoat, $\mathrm{CH}_{3} \mathrm{CN}-\mathrm{H}_{2} \mathrm{O}$ 65:35, $\left.t_{\mathrm{R}} 5.53\right)$; $\boldsymbol{S}$-(+)-18a: $[\alpha]_{\mathrm{D}}{ }^{20}+945\left(\mathrm{c} 0.25, \mathrm{CH}_{3} \mathrm{CN}\right.$ ), ee $96.6 \%$ (Kromasil 5CelluCoat, $\left.\mathrm{CH}_{3} \mathrm{CN}-\mathrm{H}_{2} \mathrm{O} 65: 35, t_{\mathrm{R}} 7.96 \mathrm{~min}\right) . \delta_{\mathrm{H}}\left(500 \mathrm{MHz}, \mathrm{CDCl}_{3}\right) 1.36\left(\mathrm{t}, 3 \mathrm{H}, \mathrm{CH}_{3}, J 7.2 \mathrm{~Hz}\right)$, 3.69 (dq, 1H, $\left.\mathrm{NCH}^{\mathrm{A}}, J 14.5,7.2 \mathrm{~Hz}\right), 3.79$ (dq, 1H, $\left.\mathrm{NCH}^{\mathrm{B}}, J 14.5,7.2 \mathrm{~Hz}\right), 5.82$ (s, 1H, H6), 6.19 (d, 1H, H4', J 3.2 Hz), 6.32 (dd, 1H, H5', J 3.2, 1.8 Hz), 7.43-7.51 (m, 4H, H3' and Ph), 7.86$7.87(\mathrm{~m}, 2 \mathrm{H}, \mathrm{Ph}) . \delta_{\mathrm{C}}\left(126 \mathrm{MHz}, \mathrm{CDCl}_{3}\right) 14.71\left(\mathrm{CH}_{3}\right), 48.82\left(\mathrm{NCH}_{2}\right), 50.84(\mathrm{C} 6), 110.07,111.03$, $111.07,111.30,116.10,118.23,127.83,128.96,131.87,133.72,144.20,145.29,147.35 . \mathrm{GC} \mathrm{t}_{R}$ $27.04 \mathrm{~min} ; \mathrm{MS} \mathrm{m} / \mathrm{z}$ (rel intensity) $302\left(\mathrm{M}^{+}, 100\right)$. Calcd. for $\mathrm{C}_{18} \mathrm{H}_{14} \mathrm{~N}_{4} \mathrm{O}$ (302.34): C 71.51, $\mathrm{H}$ 4.67, N 18.53. Found C $71.30, \mathrm{H} 4.48, \mathrm{~N} 18.75$.

1-Ethyl-6-furan-2-yl-5-thiophen-2-yl-1,6-dihydropyrazine-2,3-dicarbonitrile(18b). Yield of the racemate (see Table 1, entry 16), yellow powder, mp 102-105 ${ }^{\circ} \mathrm{C}$. Racemate was separated by chiral HPLC with a Kromasil 5-CelluCoat $(150 \times 4.6 \mathrm{~mm}, 5 \mu \mathrm{m})$ column. The eluent mixture $\mathrm{CH}_{3} \mathrm{CN}-\mathrm{H}_{2} \mathrm{O} 65: 35$ was used in isocratic mode $\left(20 \mathrm{~mL} / \mathrm{min}\right.$ at $\left.25^{\circ} \mathrm{C}\right)$, and the UV signal was monitored at $\lambda 280 \mathrm{~nm}$ to obtain the resolved enantiomeric pair $\boldsymbol{R}-(-)-\mathbf{1 8 b} / \boldsymbol{S}-(-)-\mathbf{1 8 b}\left(t_{\mathrm{R}} 5.75, t_{\mathrm{R}}\right.$ 7.10). $\boldsymbol{R}$-(-)-18b: $[\alpha]_{\mathrm{D}}{ }^{20}-906$ (c $0.25, \mathrm{CH}_{3} \mathrm{CN}$ ), ee $88.5 \%$ (Kromasil 5-CelluCoat, $\mathrm{CH}_{3} \mathrm{CN}-\mathrm{H}_{2} \mathrm{O}$ 65:35, $t_{\mathrm{R}}$ 5.27); $\boldsymbol{S}$-(+)-18b: $[\alpha]_{\mathrm{D}}{ }^{20}+1721\left(\mathrm{c} 0.25, \mathrm{CH}_{3} \mathrm{CN}\right.$ ), ee 95.2\% (Kromasil 5-CelluCoat, $\left.\mathrm{CH}_{3} \mathrm{CN}-\mathrm{H}_{2} \mathrm{O} 65: 35, t_{\mathrm{R}} 6.42\right) . \delta_{\mathrm{H}}\left(500 \mathrm{MHz}, \mathrm{CDCl}_{3}\right) 1.34\left(\mathrm{t}, 3 \mathrm{H}, \mathrm{CH}_{3}, J 7.2 \mathrm{~Hz}\right), 3.67(\mathrm{dq}, 1 \mathrm{H}$, $\left.\mathrm{NCH}^{\mathrm{A}}, J 14.5,7.2 \mathrm{~Hz}\right), 3.74\left(\mathrm{dq}, 1 \mathrm{H}, \mathrm{NCH}^{\mathrm{B}}, J 14.5,7.2 \mathrm{~Hz}\right), 5.72(\mathrm{~s}, 1 \mathrm{H}, \mathrm{H} 6), 6.23$ (d, 1H, H4', $J$ $3.4 \mathrm{~Hz}$ ), 6.33 (dd, 1H, H5', J 3.4, $1.8 \mathrm{~Hz}$ ), 7.09 (dd, 1H, H4", J 5.0, $3.8 \mathrm{~Hz}$ ), 7.42-7.43 (m, 2H, H3' and H3"), $7.56(\mathrm{dd}, 1 \mathrm{H}, \mathrm{H} 5 ", J 5.0,1.0) . \delta_{\mathrm{C}}\left(126 \mathrm{MHz}, \mathrm{CDCl}_{3}\right) 14.46\left(\mathrm{CH}_{3}\right), 48.65\left(\mathrm{NCH}_{2}\right)$, 51.74 (C6), 109.85, 110.47, 111.03, 111.34, 115.92, 118.26, 128.19, 129.71, 132.82, 140.47, 141.29, 144.09, 147.35. GC $\mathrm{t}_{R} 27.42 \mathrm{~min} ; \mathrm{MS} \mathrm{m} / \mathrm{z}$ (rel intensity) $308\left(\mathrm{M}^{+}, 100\right)$. Calcd. for $\mathrm{C}_{16} \mathrm{H}_{12} \mathrm{~N}_{4} \mathrm{OS}$ (308.36): C 62.32, H 3.92, N 18.17. Found C 62.22, H 3.77, N 18.45.

1-Ethyl-6-furan-2-yl-5-thophen-3-yl-1,6-dihydropyrazine-2,3-dicarbonitrile (18c). Yield of the racemate (see Table 1, entry 17), yellow powder, mp 103-106 ${ }^{\circ} \mathrm{C}$. Racemate was separated by chiral HPLC with a Kromasil 5-CelluCoat $(150 \times 4.6 \mathrm{~mm}, 5 \mu \mathrm{m})$ column. The eluent mixture $\mathrm{CH}_{3} \mathrm{CN}-\mathrm{H}_{2} \mathrm{O} 60: 40$ was used in isocratic mode $\left(0.8 \mathrm{~mL} / \mathrm{min}\right.$ at $\left.25^{\circ} \mathrm{C}\right)$, and the $\mathrm{UV}$ signal was monitored at $\lambda 270 \mathrm{~nm}$ to obtain the resolved enantiomeric pair $\boldsymbol{R}-(-)-\mathbf{1 8 c} / \boldsymbol{S}-(-)-18 c\left(t_{\mathrm{R}} 5.58, t_{\mathrm{R}}\right.$ 7.62). $\boldsymbol{R}$-(-)-18c: $[\alpha]_{\mathrm{D}}{ }^{20}-1112$ (c $0.25, \mathrm{CH}_{3} \mathrm{CN}$ ), ee $99.6 \%$ (Kromasil 5-CelluCoat, $\mathrm{CH}_{3} \mathrm{CN}-\mathrm{H}_{2} \mathrm{O}$ 60:40, $t_{\mathrm{R}}$ 6.60); $\boldsymbol{S}$-(+)-18c: $[\alpha]_{\mathrm{D}}{ }^{20}+982\left(\mathrm{c} 0.25, \mathrm{CH}_{3} \mathrm{CN}\right)$, ee 93.0\% (Kromasil 5-CelluCoat, $\left.\mathrm{CH}_{3} \mathrm{CN}-\mathrm{H}_{2} \mathrm{O} 60: 40, t_{\mathrm{R}} 8.93\right) . \delta_{\mathrm{H}}\left(500 \mathrm{MHz}, \mathrm{CDCl}_{3}\right) 1.34\left(\mathrm{t}, 3 \mathrm{H}, \mathrm{CH}_{3}, J 7.2 \mathrm{~Hz}\right), 3.67(\mathrm{dq}, 1 \mathrm{H}$, $\left.\mathrm{NCH}^{\mathrm{A}}, J 14.5,7.2 \mathrm{~Hz}\right), 3.74\left(\mathrm{dq}, 1 \mathrm{H}, \mathrm{NCH}^{\mathrm{B}}, J 14.5,7.2\right), 5.67$ (s, 1H, H6), 6.21 (d, 1H, H3', 3.3), 6.33 (dd, 1H, H4', J 3.3, 1.8 Hz), 7.37 (dd, 1H, H5", J 5.2, 2.8 Hz), 7.43 (dd, 1H, H5', J 1.8, $0.7 \mathrm{~Hz}), 7.63$ (dd, 1H, H4", J 5.2, $1.3 \mathrm{~Hz}), 7.75$ (dd, 1H, H2", J 2.8, $1.3 \mathrm{~Hz}) . \delta_{\mathrm{C}}(126 \mathrm{MHz}$, $\left.\mathrm{CDCl}_{3}\right) 14.54\left(\mathrm{CH}_{3}\right), 48.61\left(\mathrm{CH}_{2}\right), 51.85(\mathrm{C} 6), 109.79,110.59,111.06,111.35,116.16,118.16$, $126.96,127.13,128.59,137.93,141.93,144.08,147.44 . \mathrm{GC} \mathrm{t}_{R} 27.43 \mathrm{~min} ; \mathrm{MS} \mathrm{m} / \mathrm{z}$ (rel intensity) $308\left(\mathrm{M}^{+}, 100\right)$. Calcd. for $\mathrm{C}_{16} \mathrm{H}_{12} \mathrm{~N}_{4} \mathrm{OS}$ (308.36): C 62.32, H 3.92, N 18.17. Found C 62.12, H $3.76, \mathrm{~N} 18.44$. 
Antimycobacterial assay. To evaluate the inhibitory efficiency of molecules on Mycobacterium tuberculosis, $M$. tuberculosis $H_{37} R v$, which is susceptible to all classical antituberculosis drugs, was used. The minimal inhibitory concentration (MIC) for M. tuberculosis $H_{37} R v$ for each compound was determined by a micro broth dilution method. All molecules tested were dissolved in dimethylsulfoxide and their $1 / 2$ dilutions were prepared in $5 \mathrm{~mL}$ tubes using Löwenstein-Jensen medium. A few colonies from freshly grown M. tuberculosis $H_{37} R v$ were suspended in Löwenstein-Jensen medium to obtain 1.0 McFarland turbidity and diluted ten times using the same medium and the tubes were incubated at $37{ }^{\circ} \mathrm{C}$ medium with a different concentration of the tested molecule and to a positive control tube containing only clear growth medium. After 24 hours the tubes were placed in a vertical position and the free edge of the buried $0.3 \mathrm{~mL}$ of the substance in the test compounds concentrations: $12.5,6.2,3.1,1.5,0.75$ $\mu \mathrm{g} / \mathrm{mL}$. The tubes were then placed in an thermostat at a temperature of $37^{\circ} \mathrm{C}$ and incubated for 10 days. Growth estimate for the MTB were determined by standard methods, where the appearance of zones of growth retardation MTB (over $10 \mathrm{~mm}$ ) indicated the presence of tuberculostatic properties in concentration of the compounds under study. Penetration size stunting MTB (in $\mathrm{mm}$ ) is proportional to the degree of tuberculostatic activity. Growth delay of $100 \mathrm{~mm}$ or more is considered as a complete growth inhibition MTB. The extensively drugresistant (XDR) and multi-drug-resistant (MDR) tuberculosis strains have been isolated from tuberculosis patients in Ural Research Institute for Phthisiopulmonology (Russia). The minimal inhibitory concentrations against Mycobacterium tuberculosis avium, Mycobacterium tuberculosis terrae, XDR and MDR tuberculosis strains were evaluated similarly.

\section{Acknowledgements}

This work was supported by the Ural Branch of the Russian Academy of Sciences (Grants № 12P-3-1014, 12-P-3-1030, 12-T-3-1025, 12-T-3-1031 and 13-3-019-UMA), the Russian Foundation for Basic Research (research projects No. 13-03-96049-r_ural_a, 13-03-90606Arm_a, 14-03-01017 A and 14-03-31040-mol_a), the Council on Grants at the President of the Russian Federation (Program of State Support for Leading Scientific Schools of the Russian Federation and Young Scientists, Grant MK-3939.2014.3). Egor Verbitskiy thanks Dr. Alexey Vigorov for his personal assistance and helpful advises.

\section{References}

1. Dye, C. Lancet 2006, 367, 938. http://dx.doi.org/10.1016/S0140-6736(06)68384-0

2. World Health Organisation, Tuberculosis: http://www.who.int/mediacentre/factsheets/fs104/en/index.html (accessed June, 2013). 
3. WHO Global Tuberculosis Report, 2012.

http://apps.who.int/iris/bitstream/10665/75938/1/9789241564502 eng.pdf (accessed June, 2013).

4. Nunn, P.; Kochi, A. A. World Health 1993, 46, 7.

5. Bloom, B. R.; Murray, C. J. L. Science 1992, 257, 1055.

http://dx.doi.org/10.1126/science.257.5073.1055

6. Snider, D. E. J.; Roper, W. L. N. Engl. J. Med. 1992, 326, 703.

http://dx.doi.org/10.1056/NEJM199203053261011

7. Bass, J. B. L.; Hopewell, P. C.; O’Brein, R.; Jacobs, R. F.; Ruben, F.; Dixie, E.; Snider, J.; Thornton, G. Am. J. Respir. Crit. Care. Med. 1994, 149, 1359.

http://dx.doi.org/10.1164/ajrcem.149.5.8173779

8. Nakajima, H. World Health 1993, 46, 3.

9. Ma, Z.; Lienhardt, C.; Mc111eron, H.; Nunn, A. J.; Wang, X. Lancet 2010, 375, 2100. http://dx.doi.org/10.1016/S0140-6736(10)60359-9

10. Lalloo, U. G.; Ambaram, A. Curr. HIV/AIDS Rep. 2010, 7, 143. http://dx.doi.org/10.1007/s11904-010-0054-4

11. Cardona, P.-J., Ed. Understanding Tuberculosis-New Approaches to Fighting Against Drug Resistance, INTECHWeb.org: Croatia, 2012, ISBN: 978-953-307-948-6.

12. Porter, A. E. A. in Comprehensive Heterocyclic Chemistry I; Katritzky, A. R.; Rees, C. W.; Boulton, A. J.; McKillop, A.., Eds.; Elsevier Ltd.: Oxford, 1984; Vol. 3, Chapter 2.14., 157. http://dx.doi.org/10.1016/B978-008096519-2.00036-9

13. Sato, N. in Comprehensive Heterocyclic Chemistry II; Katritzky, A. R.; Rees, C. W.; Scriven, E. F. V.; Boulton, A.. J., Eds.; Elsevier Science Ltd.: Oxford, 1996; Vol. 6, Chapter 6.03., 233.

http://dx.doi.org/10.1016/B978-008096518-5.00119-2

14. Sato, N. in Comprehensive Heterocyclic Chemistry III; Katritzky, A. R.; Ramsden, C. A.; Scriven, E. F. V.; Taylor, R. J. K.; Aitken, A., Eds.; Elsevier Ltd.: Oxford, 2008; Vol. 8, Chapter 8.03., 273.

http://dx.doi.org/10.1016/B978-008044992-0.00703-3

15. Barlin, G. B. The Pyrazines, Wiley Interscience: New York, 1982.

http://dx.doi.org/10.1002/9780470187173

16. Brown, D. J. The Pyrazines: Suppliment I (Ser. The Chemistry of Heterociclic Compounds), Wiley Interscience: New York, 2002, 58.

17. Chupakhin, O. N.; Charushin, V. N.; van der Plas, H. C. Nucleophilic Aromatic Substitution of Hydrogen; Academic: San Diego, NewYork, 1994.

18. Rusinov, G. L.; Slepukhin, P. A.; Charushin, V. N.; Chupakhin, O. N. Mendeleev Commun. 2001, 2, 78 .

http://dx.doi.org/10.1070/MC2001v011n02ABEH001381

19. Slepukhin, P. A.; Kim, D. G.; Rusinov, G. L.; Charushin, V. N.; Chupakhin, O. N. Chem. Heterocylcic Compounds. 2002, 38, 1142. 
http://dx.doi.org/10.1023/A:1021282004750

20. Slepukhin, P. A.; Rusinov, G. L.; Charushin, V. N.; Kodess, M. I.; Chupakhin, O. N. Russ. Chem. Bull. 2003, 52, 689.

21. Slepukhin, P. A.; Rusinov, G. L.; Charushin, V. N.; Filyakova, V. I.; Karpenko, N. S.; Krivolapov, D. B.; Litvinov, I. A. Russ. Chem. Bull. 2004, 53, 1272.

22. Verbitskiy, E. V.; Rusinov, G. L.; Slepukhin, P. A.; Matern, A.I.; Shvachko, Yu. N.; Starichenko, D.V.; Charushin, V. N.; Chupakhin, O.N. Russ. Chem. Bull. 2006, 55, 2114. http://dx.doi.org/10.1007/s11172-006-0558-7

23. Verbitskii, E. V.; Rusinov, G. L.; Slepukhin, P. A.; Grishakov, A. N.; Ezhikova, M. A.; Kodess, M. I.; Charushin, V. N. Russ. J. Org. Chem. 2008, 44, 302. http://dx.doi.org/10.1134/S107042800802019X

24. Charushin, V.N.; Chupakhin, O.N.; van der Plas, H.C. Adv. Heterocycl. Chem. 1988, 43, 301. http://dx.doi.org/10.1016/S0065-2725(08)60256-1

25. Charushin, V. N.; Chupakhin, O. N. Pure and Appl. Chem. 2004, 76, 1621. http://dx.doi.org/10.1351/pac200476091621

26. Charushin, V. N.; Chupakhin, O. N. Mendeleev Commun. 2007, 17, 249. http://dx.doi.org/10.1016/j.mencom.2007.09.001

27. Petasis, N. A.; Akritopoulou, I. Tetrahedron Lett. 1993, 34, 583. http://dx.doi.org/10.1016/S0040-4039(00)61625-8

28. Petasis, N. A.; Zavialov, I. A. J. Am. Chem. Soc. 1997, 119, 445. http://dx.doi.org/10.1021/ja963178n

29. Petasis, N. A.; Goodman, A.; Zavialov, I. A. Tetrahedron 1997, 53, 16463. http://dx.doi.org/10.1016/S0040-4020(97)01028-4

30. Petasis, N. A.; Zavialov, I. A. J. Am. Chem. Soc. 1998, 120, 11798. http://dx.doi.org/10.1021/ja981075u

31. McLean, N. J.; Tye H.; Whittaker, M. Tetrahedron Lett. 2004, 45, 993. http://dx.doi.org/10.1016/j.tetlet.2003.11.092

32. Churches, Q. I.; Stewart, H. E.; Cohen, S. B.; Shröder, A.; Turner, P.; Hutton, C. A. Pure Appl. Chem. 2008, 80, 687. http://dx.doi.org/10.1351/pac200880040687

33. Candeias, N. R.; Montalbano, F.; Cal, P. M. S. D.; Gois, P. M. P. Chem. Rev., 2010, 110, 6169. http://dx.doi.org/10.1021/cr100108k

34. Hall, D. G. Boronic Acids: Preparation and Application in Organic Synthesis and Medicine, Wiley-VCH: Weinheim, 2005. http://dx.doi.org/10.1002/3527606548

35. Batey, R. A.; MacKay, D. B.; Santhakumar, V. J. J. Am. Chem. Soc. 1999, 121, 5075. http://dx.doi.org/10.1021/ja983801z

36. Petasis, N. A.; Patel, Z. D. Tetrahedron Lett. 2000, 41, 9607. http://dx.doi.org/10.1016/S0040-4039(00)01717-2 
37. Wang, Q.; Finn, M. G. Org. Lett. 2000, 2, 4063.

http://dx.doi.org/10.1021/ol006710r

38. Berree, F.; Debache, A.; Marsac, Y.; Carboni, B. Tetrahedron Lett. 2001, 42, 3591. http://dx.doi.org/10.1016/S0040-4039(01)00515-9

39. Smith, A. B. III; Minbiole, K. P.; Verhoest, P. R.; Schelhaas, M. J. Am. Chem. Soc. 2001, $123,10942$.

http://dx.doi.org/10.1021/ja0116041

40. Smith, A. B. III; Safonov, I. G.; Corbett, R. M. J. Am. Chem. Soc. 2001, 123, 12426. http://dx.doi.org/10.1021/ja012220y

41. Klopfenstein, S. R.; Chen, J. J.; Golebiowski, A.; Li, M.; Peng, S. X.; Shao, X. Tetrahedron Lett. 2000, 41, 4835.

http://dx.doi.org/10.1016/S0040-4039(00)00668-7

42. Golebiowski, A.; Klopfenstein, S. R.; Chen, J. J.; Shao, X. Tetrahedron Lett. 2000, 41, 4841. http://dx.doi.org/10.1016/S0040-4039(00)00669-9

43. Schlienger, N.; Bryce, M. R.; Hansen, T. K. Tetrahedron 2000, 56, 10023. http://dx.doi.org/10.1016/S0040-4020(00)00957-1

44. Rusinov, G. L.; Slepukhin, P. A.; Charushin, V. N.; Dyachenko, O. A.; Kazheva, O. N.; Chekhlov, A. N.; Verbitsky, E. V.; Kodess, M. I.; Chupakhin, O. N. Mendeleev Commun., 2006, 16, 26.

http://dx.doi.org/10.1070/MC2006v016n01ABEH002153

45. Verbitskiy, E. V.; Berezin, M. V.; Slepukhin, P. A.; Rusinov, G. L.; Charushin V. N. Russ. Chem. Bull. 2009, 58, 176.

http://dx.doi.org/10.1007/s11172-009-0027-1

46. Rusinov, G. L.; Verbitskiy, E. V.; Slepukhin, P. A.; Zabelina, O. N.; Kodess, M. I.; Ezhikova, M. A.; Charushin, V. N.; Chupakhin, O. N. Heterocycles, 2009, 78, 2315. http://dx.doi.org/10.3987/COM-09-11734

47. Rusinov, G. L.; Verbitsky, E. V.; Slepukhin, P. A.; Zabelina, O. N.; Ganebnykh, I. N.; Kalinin, V. N.; Ol'shevskaya, V. A.; Charushin, V. N. Mendeleev Commun. 2009, 19, 243. http://dx.doi.org/10.1016/j.mencom.2009.09.002

48. Verbitskiy, E. V.; Slepukhin, P. A.; Ezhikova, M. A.; Kodess, M. I.; Rusinov, G. L.; Charushin, V. N. Russ. Chem. Bull. 2009, 58, 1291. http://dx.doi.org/10.1007/s11172-009-0169-1

49. Verbitskiy, E. V.; Kvashnin, Yu. A.; Slepukhin, P. A.; Kuchin, A. V.; Rusinov, G. L.; Chupakhin, O. N.; Charushin, V. N. Russ. Chem. Bull. 2011, 60, 919. http://dx.doi.org/10.1007/s11172-011-0144-5

50. Verbitskiy, E. V.; Slepukhin, P. A.; Ezhikova, M. A.; Kodess, M. I.; Shvachko, Yu. N.; Starichenko, D. V.; Rusinov, G. L.; Charushin, V. N. Russ. Chem. Bull. 2011, 60, 975. http://dx.doi.org/10.1007/s11172-011-0153-4

51. Chang, Y. M.; Lee, S. H.; Nam, M. H.; Cho, M. Y.; Parka Y. S.; Yoon, C. M. Tetrahedron Lett. 2005, 46, 3053. 
http://dx.doi.org/10.1016/j.tetlet.2005.03.008

52. Tietze, F. L.; Eicher, T. Reaktionen und Synthesen im organisch-chemischen Praktikum und Forschunglaboratorium; Georg Thieme Verlag Stuttgart: New York, 1991.

53. Sheldrick, G.M. Acta Cryst. 2008, A64, 112.

http://dx.doi.org/10.1107/S0108767307043930

54. Dolomanov, O. V.; Bourhis, L. J.; Gildea, R. J. ; Howard, J. A. K.; Puschmann, H. J. Appl. Cryst. 2009. 42, 339.

http://dx.doi.org/10.1107/S0021889808042726 